
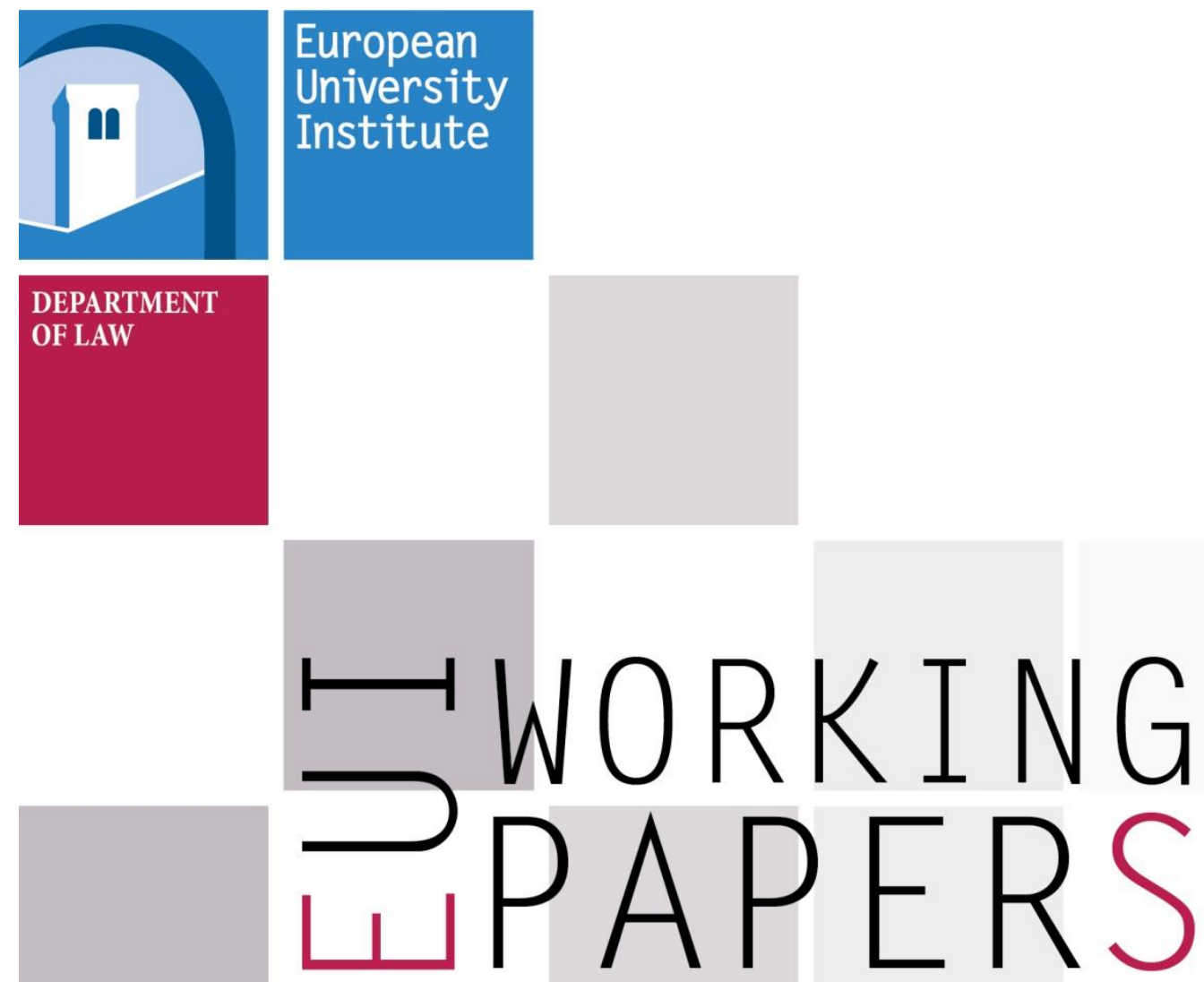

LAW 2015/20

Department of Law

Credit Bureaus Between Risk-Management, Creditworthiness Assessment and Prudential Supervision

Federico Ferretti 

European University Institute

Department of Law

\section{Credit Bureaus Between Risk-Management, Creditworthiness ASSESSMENT AND Prudential SUPERVISION}

Federico Ferretti

EUI Working Paper LAW 2015/20 
This text may be downloaded for personal research purposes only. Any additional reproduction for other purposes, whether in hard copy or electronically, requires the consent of the author. If cited or quoted, reference should be made to the full name of the author, the title, the working paper or other series, the year, and the publisher.

ISSN 1725-6739

(C) Federico Ferretti, 2015

Printed in Italy

European University Institute

Badia Fiesolana

I-50014 San Domenico di Fiesole (FI)

Italy

www.eui.eu

cadmus.eui.eu 
Authors' contact details

\section{Federico Ferretti}

Senior Lecturer in Law

Brunel Law School, Brunel University London

United Kingdom

Federico.Ferretti@brunel.ac.uk 


\begin{abstract}
This paper discusses the role and operations of consumer Credit Bureaus in the European Union in the context of the economic theories, policies and law within which they work. Across Europe there is no common practice of sharing the credit data of consumers which can be used for several purposes. Mostly, they are used by the lending industry as a practice of creditworthiness assessment or as a riskmanagement tool to underwrite borrowing decisions or price risk. However, the type, breath, and depth of information differ greatly from country to country. In some Member States, consumer data are part of a broader information centralisation system for the prudential supervision of banks and the financial system as a whole. Despite EU rules on credit to consumers for the creation of the internal market, the underlying consumer data infrastructure remains fragmented at national level, failing to achieve univocal, common, or defined policy objectives under a harmonised legal framework. Likewise, the establishment of the Banking Union and the prudential supervision of the Euro area demand standardisation and convergence of the data used to measure debt levels, arrears, and delinquencies. The many functions and usages of credit data suggest that the policy goals to be achieved should inform the legal and institutional framework of Credit Bureaus, as well as the design and use of the databases. This is also because fundamental rights and consumer protection concerns arise from the sharing of credit data and their expanding use.
\end{abstract}

\title{
Keywords
}

Consumers, credit data, over-indebtedness, creditworthiness, prudential supervision 


\section{Table of contents}

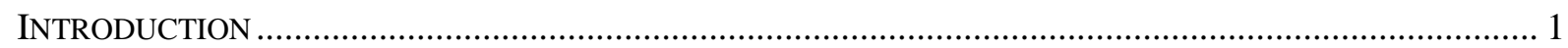

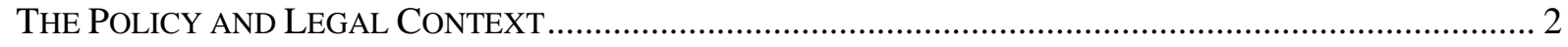

Responsible lending, over-indebtedness and creditworthiness assessment …….............................................. 2

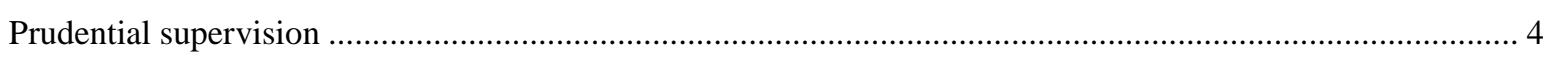

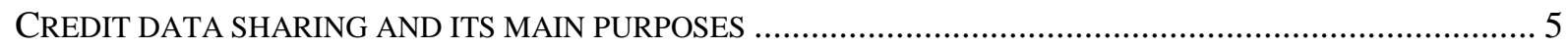

The Reduction of Information Asymmetry and Risk-Management ................................................ 5

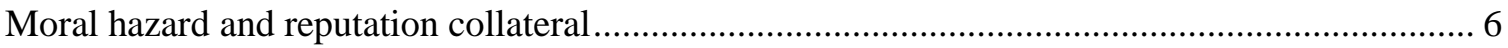

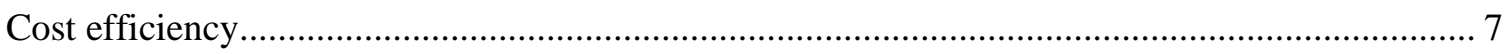

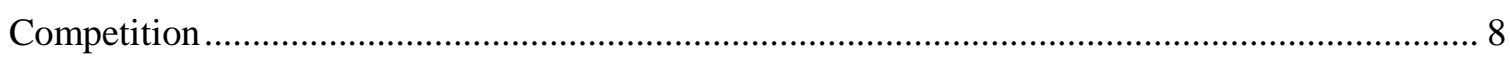

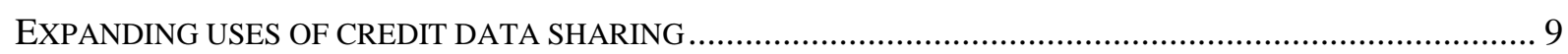

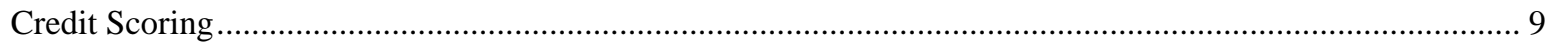

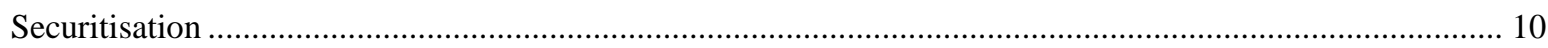

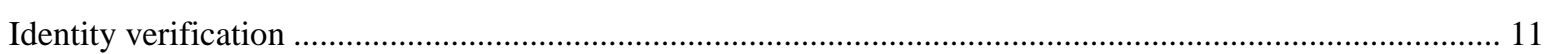

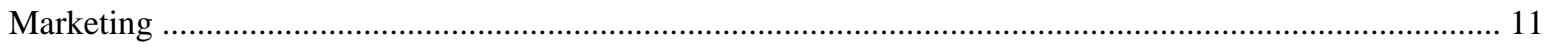

Fraud prevention

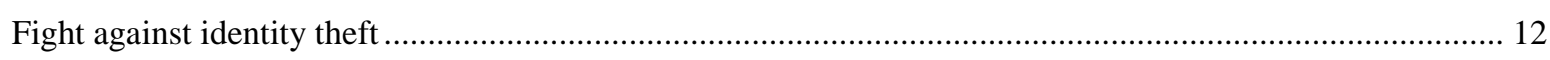

Emerging uses: job applications, tenancies, and uses in other economic sectors ........................................... 12

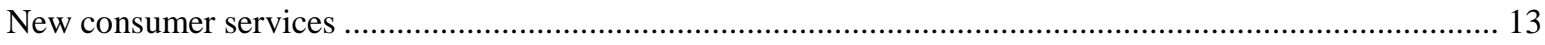

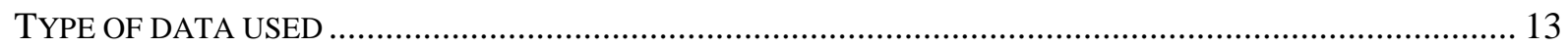

THE LEGAL FORM AND FUNCTIONS OF CREDIT BUREAUS IN THE EU ................................................. 16

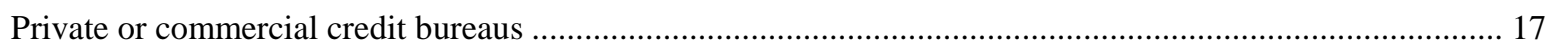

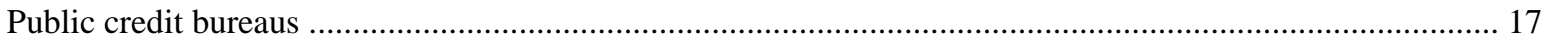

RELIABILITY AND PROPORTIONALITY OF DATA TO ACHIEVE POLICY OBJECTIVES ............................... 20

CROSS-BORDER EXCHANGE OF DATA AND INTEGRATION OF CREDIT MARKETS ...................................... 22

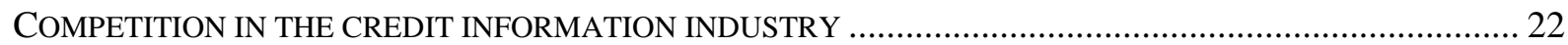

CONSUMER PROTECTION CONCERNS BEYOND DATA PROTECTION: CREDIT DATA AS THE GATEWAY OF

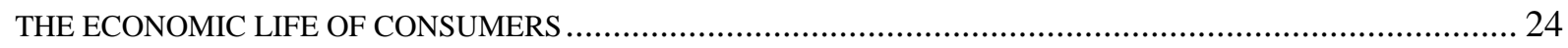

PROSPECTS FOR A EU STANDARDISATION AND SHARED SYSTEM OF CREDIT DATA.............................. 25

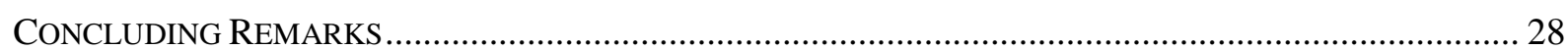





\section{Introduction}

This study provides an overview of the role and operations of consumer Credit Bureaus in the Member States of the EU and it analyses their functions within the EU policy and legal framework.

It is difficult to provide at an introductory stage a standard definition or explanation of what exactly Credit Bureaus are. The complexity arises from the fact that their activities and functions in the economy differ significantly within the EU, depending largely on national cultures and traditions, institutional arrangements and the economic and regulatory environment.

One of the aims of this work is to provide some clarity and disentangle such a difficulty.

Broadly, Credit Bureaus may be described as third-party private, commercial, or public organisations that collect a variety of financial data of consumers about transactions with credit providers and, depending on the practices in the Member States, other providers that are not financial institutions stricto sensu but that advance goods or services to consumers that will be paid at a later stage (e.g. utility companies, telecoms, mail order companies, etc.). Such data are pooled to compile databases, and the information is shared among the lenders who are part of the information network.

Consumer data sharing has become the instrument most extensively used by the credit industry to assess consumers' creditworthiness and underwrite decisions on borrowings or the supply of goods and services. As such, it is used for credit-risk management in the private interest of lenders or as a practice of creditworthiness assessment. However, under certain national systems, consumer data are part of a broader information centralisation system managed by national central banks for the purpose of oversight of the financial system as a whole, i.e. they are an instrument for the prudential supervision of the banking system.

Whatever the arrangements and the function of a sharing system in the national jurisdictions, the financial information of consumers and its uses are the basis of any Credit Bureau operation. As such, difficult questions arise over the privacy and data protection of consumers vis-à-vis the purposes and the necessity of its uses. After all, privacy and data protection are fundamental rights of the EU legal system under Article 16 TFEU and Articles 7 and 8 of the Charter of the Fundamental Rights of the EU.

In this paper the legal analysis of data protection law has been voluntarily left unattended for the specificity of the issues that it generates. Rather, the focus is an investigation of the economic policies of consumer data sharing by Credit Bureaus, the legal responses, and consumer protection beyond privacy and data protection rights.

Section 1 explores the broad policy and legal context within which Credit Bureaus operate. At first, it analyses credit data vis-à-vis responsible lending policies and the legal transposition of the creditworthiness assessment to tackle the over-indebtedness of European consumers, digging into the relevant provisions of the Consumer Credit Directive and the Mortgage Credit Directive. Next, the use of financial information for the prudential supervision of the banking system is accounted to underline a separate but intersecting role of information in credit markets and the ensuing legal and institutional legal arrangements.

The economic theories, purposes and traditional uses of credit data are analysed in Section 2. These include the reduction of information asymmetries between lenders and borrowers, the use of information in credit-risk management and decision-making in the interest of creditors, the prevention of moral hazard of consumers and information sharing as reputation collateral, the implementation by creditors of cost-efficient mechanisms for screening applications and managing accounts of consumers, and data pooling and sharing to enhance competition by lenders in consumer credit markets. 
Section 3 touches upon the expanding uses of credit data to show how the credit information industry has moved forward with the use of consumer data to develop new services for the credit industry and serve their economic interests. Such uses include credit scoring, rating and tools for credit products' securitisation, information matching for identity verification, marketing services and consulting, technological tools to help lenders in fraud prevention, and emerging uses beyond the creditor-debtor traditional relationship.

The variety of information used by Credit Bureaus in the Member States is reported in Section 4, which contains comparative Tables of the type of data in each national jurisdiction of the EU, outlining the considerable differences in the activities of Credit Bureaus and how the EU market for data is jeopardised into national markets.

All the above differences are reflected in the diverse legal forms and functions of Credit Bureaus across the EU. Section 5 explains the private and/or commercial character of Credit Bureaus in a number of Member States vis-à-vis the public nature and function in prudential supervision of Credit Bureaus in other Member States, all having in common the centralisation and sharing of information but under different rules of participation and legal framework. Once more, comparative Tables aim at illustrating the fragmented picture across the EU.

The following Sections aim at identifying shortcomings in the current structure and arrangements in consumer data sharing within the context of the EU and its policies.

Section 6 attempts to analyse and question the use of consumer data against problems of reliability and proportionality of the data used to achieve the policy goals that the sharing intends to achieve.

Similarly, Section 7 looks at the limitations of the cross-border exchange of data in view of the EU integration of credit markets and the law in place to achieve an internal market in credit for consumers, advancing questions as to the extent to which the fragmentation of the information market affects the credit market that it serves.

The latter issue touches into the unexplored territory of competition among the Credit Bureaus where their nature of natural monopolies is confronted with the limitations of the cross-border exchange of data. This is the issue briefly addressed by Section 8 .

Section 9, in turn, takes the angle of consumer protection beyond the problems usually addressed by personal data protection law. The major concern that it explores is the problem of the use of credit data as a gateway of the economic and social life of consumers, as well as the lack of proper safeguards in place to prevent this to happen or to address issues of consumer access to products and services.

Finally, Section 10 observes the latest developments and initiatives taken at EU level to standardise credit data for statistical purposes measure consumer over-indebtedness. In particular, it examines the projects of the European Central Bank and its implementing legal measures to centralise and standardise credit information for statistical purposes under the umbrella of its new remit over the prudential supervision of the banking system. It concludes with a speculation over the likely interference with the activities of Credit Bureaus, the setting of standards, and the blurring functions of credit-risk management, creditworthiness assessment, and prudential supervision of credit institutions.

\section{The Policy and Legal Context}

\section{Responsible lending, over-indebtedness and creditworthiness assessment}

The market for loans available to consumers has grown rapidly in the last decade across the EU and it is becoming increasingly sophisticated. However, with the development of the retail and mortgage credit markets European consumers are becoming increasingly indebted. The growth of overindebtedness is becoming a concern for national and EU policy-makers alike. Besides, the financial 
crisis has raised important issues regarding the protection of consumers in financial markets and the need for additional safeguards to stem the social problems that it has exacerbated. ${ }^{1}$

Therefore, alongside the advancement of measures for the cross-border provision of credit and the abolition of obstacles for further integration, the promotion of responsible lending and borrowing policies to limit the over-indebtedness of European consumers is high on the EU agenda. Likewise, the importance of the relationship between borrowers and financial institutions is under the close scrutiny of European policy makers.

Responsible lending and borrowing is a recent policy introducing a novel concept to tackle consumers' over-indebtedness. It makes reference to the delivery of responsible and reliable markets, as well as the restoration of consumer confidence, where credit products are appropriate for consumers' needs and are tailored to their ability to repay their debts. They envisage a framework that could ensure that all lenders and intermediaries act in a fair, honest and professional manner before, during, and after the lending transaction. Similarly, it is expected that in order to obtain credit consumers provide relevant, complete and accurate information on their finances. They are also encouraged to make informed and sustainable borrowing decisions. ${ }^{2}$

The resulting EU law regarding loans to consumers comprises the Consumer Credit Directive (CCD ${ }^{3}$ and the Mortgage Credit Directive (MCD). ${ }^{4}$

The relevant provisions are contained in Articles 8 and 9 of the CCD and Articles 18, 20, and 21 of the MCD.

The CCD is not explicit and it is to some extent unclear on the exchange of consumer information, at least as far as the obligation to share information is concerned. Article 8 of the CCD states that creditors have to assess the consumer's creditworthiness on the basis of sufficient information obtained from the consumer, not through information exchanges. Only where it is necessary, financial institutions have to make such assessment on the basis of a consultation of the relevant database, such circumstance occurring in those Member States whose legislation requires them to consult databases, usually a requirement that may be imposed by central banks for purposes of financial stability (see the relevant sub-heading below in this Section).

At the same time, in the following Article 9 the CCD is concerned that for competition purposes access is ensured on a non-discriminatory basis for creditors from other Member States to databases used in another Member State, if any.

\footnotetext{
${ }^{1}$ See European Commission, Staff Working Paper on National Measures and Practices aimed at Avoiding Foreclosure Procedures for Residential Mortgage Loans SEC(2011) 357 final, which pointed to the severe consequences for individual homeowners losing their homes in a foreclosure procedure, but also for society as a whole, considering their impact on financial and social stability.

${ }^{2}$ See Communication of the European Commission to the European Council of 4 March 2009 Driving European Recovery, COM (2009) 114. See also the Public Consultation on Responsible Lending and Borrowing, available atec.europa.eu/internal.../responsible_lending/consultation_en.pdf. the EU Commission has conducted a consultation with all stakeholders on responsible lending and borrowing in the EU to find measures to adequately assess, by all appropriate means, borrowers' creditworthiness before granting them a loan and tackle over-indebtedness. The consultation covered, among other things, the advertising and marketing of credit products, the information to be provided to borrowers prior to granting any loans, ways to assess product suitability and borrower creditworthiness, advice standards, responsible borrowing and issues relating to the framework for credit intermediaries (for example, disclosures, registration, licensing and supervision).

${ }^{3}$ Directive 2008/48/EC of the European Parliament and of the Council of 23 April 2008 on credit agreements for consumers and repealing Council Directive 87/102/EEC, OJ 2008 L 133/66.

${ }^{4}$ Directive 2014/17/EU of the European Parliament and of the Council of 4 February 2014 on credit agreements for consumers relating to residential immovable property and amending Directives 2008/48/EC and 2013/36/EU and Regulation (EU) No 1093/2010, OJ 2014 L 60/34.
} 
Likewise, the final text of the MCD provides for an obligation for lenders to assess the creditworthiness of consumers before granting a loan. In such an assessment, it requires that creditors take appropriate account of a number of relevant factors, requiring financial institutions to obtain information directly from the consumer, with the addition of relevant internal or external sources but without explicating information exchanges among lenders as the necessary 'external source' to be used. Relevant factors include income, savings, assets, expenses, features of the loan of offer, etc. Credit data are one of many possible sources of information for the assessment of creditworthiness. ${ }^{5}$

At the same time, like the CCD, the MCD looks at the competition side of the market and it provides for the non-discriminatory access of creditors to the databases used in another Member States via the exchange of information among the competing creditors, specifying that such databases comprise databases operated by private information providers as well as public registers. ${ }^{6}$

The focus on competition of the MCD is clear from the Recitals:

to prevent any distortion of competition among creditors, it should be ensured that all creditors, including credit institutions or non-credit institutions providing credit agreements relating to residential immovable property, have access to all public and private credit databases concerning consumers under non-discriminatory conditions $(\ldots)^{7}$

Importantly, both the $\mathrm{CCD}$ and the MCD state that such provisions are without prejudice to the application of the EU data protection law on the protection of individuals with regard to the processing of personal data and on the free movement of such data, whose provisions must be respected, particularly as far as the requirements of 'necessity' and 'proportionality' of the processing are concerned. ${ }^{8}$

Against such policy and legal context, on the one hand the exchange of credit data may be regarded in the benefit of consumers. On the other hand, however, it remains open to debate whether the design of databases is proportionate to the policy goals to be achieved, and whether the level of aggregation or detail of information exceeds the purpose for its sharing. In turn, the first issue raises debates over duties and social responsibilities and the institutions which should be entrusted with the exercise of the social function of controlling over-indebtedness in the interest of consumers, as well as the oversight of system. ${ }^{9}$

\section{Prudential supervision}

Information exchanges among competing lenders may be justified and used for the supervision of the financial system as a whole.

Financial prudential supervision encompasses a number of complex issues and elements that are beyond the scope of this work. But, among the tools to achieve it, there is the need for the authorities in charge of this public function to have adequate and timely information about the behaviour, leverage, and condition of banks vis-à-vis the whole system. Among the many types of information needed by the authorities - such as asset quality, capital adequacy, liquidity, internal systems of control and security, income and dividends, foreign operations, and so on - it is included the regular reporting on past due loans and non-performing loans. This not only allows supervisors to be in control and have the information on the condition and performance of the supervisees to intervene in

\footnotetext{
${ }^{5}$ See Article 18 and 20 of the MCD.

${ }^{6}$ See Article21 of the MCD. See, also, European Banking Authority, Opinion of the European Banking Authority on Good Practices for Responsible Mortgage Lending (London, 13 June 2013).

${ }^{7}$ Recital 60 of the MCD.

${ }^{8}$ See Article 9(4) of the CCD, and Recitals 59, 61, and 62 of the MCD.

${ }^{9}$ Ferretti (2010), pp. 1-27.
} 
time in case of problems, but it also constitutes an instrument to promote transparency to favour greater reliance on market discipline. Banks benefit from supervision in that they are provided with the instruments to control the quality of their loans in their daily operations. To favour this, in a number of Member States centralised databases managed by public authorities provide banks and supervisors with aggregate information about the level of indebtedness of borrowers vis-à-vis the whole system, including natural persons. In these jurisdictions, information sharing by supervised banks is mandated by law, usually in the national banking act. ${ }^{10}$

This mechanism relies on information exchanges among competing financial institutions where the public authority acts as the third-party pooling, aggregating, and elaborating the information exchanged, as well as the organisation setting the rules of the information exchanges.

The exchange of private financial information in this context may become clearer below in the discussion of the information providers and their role which, in turn, will later result helpful for matters of competition law and policy.

\section{Credit data sharing and its main purposes}

\section{The Reduction of Information Asymmetry and Risk-Management}

Classical economic theory views the sharing of consumer credit data in the financial system as a tool to meet the problem of asymmetrical information between borrowers and lenders, as well as problems of bad selection of customers, and the risk which arises from the characteristics of prospective borrowers that may increases the possibility of an economic loss.

Economists have identified the problem of asymmetrical information as the one that a party has when it does not have the same information of the other party in relation to the risks relating to the performance of the contract by such other party. In a nutshell, one party knows less than the other, a situation which is different from the one where a party has less information than the ideal, known as 'imperfect information'.

In finance, this may be seen as the different knowledge or level of information that the demand side, i.e. customers, has either on financial products or the market behaviour of providers. By the same token, from the perspective of the supply side of the relationship, i.e. the credit industry, this difference of knowledge or information relates to the payment behaviour of customers. In a credit relationship, lenders want to avoid lending money that will not be repaid. If they do not have the same information as borrowers have on their ability or willingness to repay a debt, they will incur in a higher risk of making bad business. This risk, in turn, poses problems of bad debts and adverse selection, i.e. the selection of the wrong customers. This explains why economic theory has traditionally emphasised the importance of information in credit markets. ${ }^{11}$

From the supply side, the reduction of asymmetric information and adverse selection of customers encompass several elements relating to market structure and marketing activities of the participants in the retail finance marketplace.

10 Jappelli and Pagano (2000); Jappelli and Pagano (2003), pp. 81-114; Jappelli and Pagano (2006), pp. 347 371; Ferretti (2008); Brealey, Clark, Goodhart, Healy, Hoggarth, LLewllyn, et al. (2001), sp. Ch. 2; Cartwright (2004), sp. 31-34; Lastra (1996); Lastra and Shams (2001), pp. 165-188.

${ }^{11}$ Stiglitz and Weiss (1981), pp. 393-410; Berger and Udell (1995), pp. 351-381; Akelof (1970), pp. 523-547; Diamond (1991), pp. 689-721; Admati and Pfleiderer (2000), pp. 479-519. 
The theory suggests that the lack of information on borrowers can prevent the efficient allocation of credit in a market, and that one way that lenders can improve their knowledge of borrowers is through their observation of clients over time. ${ }^{12}$

In turn, the reduction of asymmetric information affects many aspects of the lending business: risk management and pricing through the assessment of uncertainties about the ability and/or willingness of a debtor to repay, market entry and competition, customers' creditworthiness, application processing and screening, customers' segmentation and product specialisation, and improvement of the credit portfolio. ${ }^{13}$

\section{Moral hazard and reputation collateral}

All financial transactions in general, and credit transactions in particular, involve risks or uncertainties. Among these, an important one concerns the ability and/or the willingness of the debtor to repay the debt. At the time of contracting, lenders want to assess whether borrowers are creditworthy, i.e. if they have the ability to pay when the repayment is due back, and/or that they have the willingness and incentive to pay back their debt. These are two different types of risk because some people may be able to pay but unwilling to do it or, vice versa, they do want to pay but due to unexpected changes in their circumstances they may be unable to pay back when the money is due.

The unwillingness to repay is known as 'moral hazard'. It refers to the risk which arises from personal, as distinguished from physical, characteristics of a borrower that increases the possibility of an economic loss. It is a phenomenon normally associated with business credit: it occurs when entrepreneurs have incentives to invest in riskier projects and a larger proportion of the cost is financed by a lender. If the project is successful, they have much to gain from any excess return, but if the project fails their losses would be limited by bankruptcy. Hence, in this circumstance, as lenders will suffer much of the actual economic losses, borrowers do not have incentives to act prudently and exceed in risk-taking in the attempt to maximise returns. Investments, by contrast, are deemed to become capable of being safer if entrepreneurs have more to lose, in particular if they are forced to bear a portion of the risk. ${ }^{14}$

But moral hazard is now considered directly relevant also for the behaviour of consumers in the use of mortgage or consumptive credit every time that a repayment reflects the willingness, not the ability, to honour one's debts. In credit to consumers, individuals do not make risky investments but they use credit to consume or buy a property. ${ }^{15}$ As the theory explains, when deciding to repay, a rational agent weighs the gain of failing to repay vis-à-vis the punishment for default. Since small-size debts could not be cost-effective to recover by lenders, and debtors may receive no or little punishment by the law, a number of consumers may become prone to moral-hazard, i.e. they willingly may decide not to repay their debts. ${ }^{16}$

Similarly, economic theory also explains that information exchanges among lenders play a pivotal role as a borrowers' discipline device as the latter would know that a delay or a default in re-payment

\footnotetext{
${ }^{12}$ Ibid.

${ }^{13}$ Ibid.

${ }^{14}$ Bertola, Disney, and Grant (2006 a), pp. 1-26.

15 Of course, high levels of indebtedness are risky for consumers who may be exposed to economic shocks and overindebtedness. For example, this is why Sweden is proposing new legislation forcing amortisation requirements which demands mortgage holders to repay more than they currently do, especially if they have borrowed high percentages of the purchase price of their home. See the official website of the Swedish central administrative body in charge of monitoring and analysing the trends in the financial market (Finansinspektionen) at http://www.fi.se/upload/90_English/80_Press_office/2014/measures-household-indebtedness-eng.pdf.

${ }^{16}$ Bertola, Disney, and Grant (2006 a), pp. 1-26.
} 
compromise their reputation with all the other potential lenders on the market, resulting in credit with more costly terms or by cutting them off from credit entirely. ${ }^{17}$ Therefore, information exchanges among lenders would strengthen borrower discipline and reduce moral hazard, since late payment or failure to repay a debt with one institution would result in sanctions by all or many others. According to Miller, a borrower's 'good name', i.e. his or her reputation collateral, should provide "an incentive to meet commitments much the same way as does a pledge of physical collateral, thus reducing moral hazard". ${ }^{18}$

From this perspective, some have gone as far as suggesting that information exchanges maintain accountability and honesty in society. ${ }^{19}$

\section{Cost efficiency}

Typically, the process of granting credit begins when a prospective customer approaches a credit provider and applies for credit or services/goods to be paid at a later stage. In the event the latter agrees to enter the financing or credit agreement, then, such a relationship ends when the last statement of the credit line is paid back in accordance with the same agreement or, in the worst case scenario, when the credit is unrecoverable and/or disregarded following a debt recovery proceeding and a judicial procedure, or in some jurisdictions the judicial declaration of insolvency of the borrower. The recourse to debt collection procedures and legal actions, however, does not guarantee to lenders the recovery of the debt and, in any event, they are considered an instrument of last resort as they are perceived to be both costly and time-consuming. ${ }^{20}$

Thus, risk assessment and applicants screening have become particularly important for the consumer credit industry which has to deal with a large number of small-sum (often unsecured) credit lines. It is widely agreed, in fact, that in this sector profitability is only achieved by minimising the risk while ensuring that a sizeable volume of credit lines is granted. Hence, credit grantors consider information about borrowers vital for their risk-assessment purposes. Along these lines, one of the best predictors of future behaviour is considered to be past behaviour. Therefore, information on how a potential borrower has met obligations in the past enables lenders to more accurately evaluate credit risk, easing adverse selection problems. ${ }^{21}$

Moreover, the small or medium size of loans to consumers means that it is not cost-efficient to assess consumers on a case by case basis. Traditionally, when lenders evaluate borrowers to determine their creditworthiness for credit-risk assessment and management, they interview the applicants and ask them directly for personal information together with the relevant supporting documents. At the same time, they seek and gather information from their own databases developed through years of experience and business practice in the credit market. Such a source of information, however, is incomplete as it covers a lender's own past and present customers, but it does not contain data about the same customers' past and/or present relationship with other financial institutions nor, from a competition perspective, information about new or prospective customers and their past and/or present relationship with other providers. Thus, it is with the view to supplement comprehensive information

\footnotetext{
${ }^{17}$ Jappelli and Pagano (2002), pp. 2017-2045; Diamond (1991), pp. 689-721; Admati and Pfleiderer (2000), pp. 479-519. See also Jappelli and Pagano (2006), pp. 347-371.

${ }^{18}$ Miller (2003 a), pp. 1-23, sp. 2. See also Miller (2003 b), pp. 25-79.

${ }^{19}$ Klein (1992), pp. 117-136; Klein (1997), pp. 267-288.

${ }^{20}$ Riestra (2002), p 4; Bertola, Disney, and Grant (2006), pp. 1-26.

${ }^{21}$ Miller (2003 a), pp. 1-23, sp. 2. See also Miller (2003 b), 25-79.
} 
about these customers that information exchanges among lenders and sophisticated centralised databases emerged and developed in the past few decades. ${ }^{22}$

\section{Competition}

As far as competition is concerned, the exchange of information on customer relationships or applicants reduces the information monopoly of individual lenders and the competitive advantage of large financial institutions. Although lenders lose the exclusivity of data in terms of competition one versus the other, they would ultimately gain by sharing information as this additional accumulation of data enables them to distinguish the good borrowers from the bad ones. Information sharing would serve as a tool to predict the future payment behaviour of applicants allowing lenders to attract creditworthy borrowers and offering them better terms and conditions, thus promoting market competition that could ultimately result in benefits to those 'good consumers' ${ }^{23}$ Hence, the adverse selection problem identified by the economic literature indicates that should lenders fail to distinguish the good borrowers from the bad ones, all accepted borrowers would be charged at a higher rate an average interest rate that mirrors their pooled experience. ${ }^{24}$ Therefore, the distinction between good borrowers from the bad ones allows lenders on the one hand to offer more advantageous prices to lower-risk borrowers while, on the other hand, higher risk borrowers are offered higher interest rates or can be rationed out of the market because of the lenders' unwillingness to offer these borrowers accommodating rates or any credit at all. ${ }^{25}$

The problem of asymmetric information and adverse selection becomes greater for new market entrants, particularly foreign lenders. This is particularly the case in the context of the creation of the EU single market and cross-border entry or cross-border provision of financial services. In addition to competitive disadvantages in relation to incurring greater risks of incorrectly estimating a borrower's credit risk, without relevant information on borrowers new market entrants would be likely to attract precisely those who were rejected by existing lenders in the market. ${ }^{26}$ This circumstance has induced recent literature to conclude that information sharing, market structure, and competitive conduct are intrinsically intertwined in the financial services market and, from the standpoint of industrial organisation, the availability of information shared by the sector can affect foreign lenders' choice not only of whether to entry another jurisdiction but also the mode of doing it, i.e. whether through the cross-border provision of services, the setting-up of branches or subsidiaries, or through mergers and acquisitions. ${ }^{27}$

Therefore, on the one hand such strategies may well have the potential to influence the intensity of competition in national markets and among national providers. On the other hand, however, this is an indication that the behaviour of one or few market players - particularly existing lenders - influences and drives the behaviour of others, especially new entrants, which will decide their strategies on the experience, or market intelligence, of existing ones.

Prima facie, considerations of the like may have the effect of casting doubts as to whether or to what extent in actual facts this may constitute a concerted practice or simply a reduction of market uncertainty. ${ }^{28}$

\footnotetext{
22 Bertola, Disney, and Grant (2006), pp. 1-26; Riestra (2002). However, note that in some countries (e.g. Germany) credit bureaus have been existing for a longer time (see Sections 5.1 and 5.2 below).

23 European Commission (2009).

24 Alary and Gollier (2001).

25 Barron and Staten (2000); Barron and Staten (2003), pp. 273-310.

${ }^{26}$ Giannetti, Jentzsch, and Spagnolo (2010).

27 Ibid.

${ }^{28}$ Ferretti (2014).
} 
Also, to the extent that information monopoly of individual lenders is reduced, this is transferred to those third-party subjects who become the providers of information and manage the corresponding databases, i.e. the Credit Bureaus.

This, in turn, may raise new concerns over market competition and power which are beyond the scope of this work. ${ }^{29}$

\section{Expanding uses of credit data sharing}

\section{Credit Scoring}

Credit scoring is a related, yet distinct, use of credit data that avails itself of ad hoc technologies which add additional features and integrate the data with other data sources. Scoring models are mathematical algorithms or statistical programmes that determine the probable repayments of debts by consumers, assigning a score to an individual based on the information processed from a number of data sources and categorising credit applicants according to risk classes. They involve data mining techniques which include statistics, artificial intelligence, machine learning, and other fields aiming at getting knowledge from large databases. ${ }^{30}$

Scoring has been subject to several criticisms for its numerous fallacies, particularly for introducing new biases, or for making assumptions that lack universal acceptance or that may work on large numbers but not for individual cases. ${ }^{31}$

In the end, scoring is essentially a classification and profiling technique, a way of recognising different groups in a population according to certain features expressed by a combination of personal financial and other non-personal data, differentiating consumers on grounds of parameters and classifications set a priori from statistics for a predictive purpose. It is an analysis of customer behaviour having the objective of classifying them in two or more groups based on a predictive outcome associated with each customer. The probability of given events, such as for example a default in the repayment of a loan, is assumed to depend on a number of characteristics of the individuals ${ }^{32}$ The factors relevant for such a classification purpose are usually determined through an analysis of consumers' past payment history together with other descriptive information provided in the credit application form and other data from a number of different sources.

In short, a goal of credit scoring systems in the lending process is that of predicting the risk or assessing through automated means the creditworthiness of consumers, as well as the profitability of lenders over each one of them. It is now used for all consumer credit operations, in issuing credit cards and managing accounts, as well as in mortgage origination and securitisation operations of consumer loans. Although credit scoring was originally employed to seek to minimise the percentage of consumers who default, lenders are now using it to identify the customers who are most profitable and to maximise profits through risk-based pricing according to their profile thus obtained, blurring all this with direct marketing activities. ${ }^{33}$

\footnotetext{
${ }^{29}$ These issues have been addressed in Ferretti (2014).

${ }^{30}$ See, for example, Bigus (1996); Desai, Convay, Crook, and Overstree (1997), pp. 323-346; Handzic, Tjandrawibawa, and Jeo (2003), pp. 97-109; Jensen (1992), pp. 15-26; Yobas and Crook (2000), pp. 111-125.

${ }^{31}$ For all see, for example, Poulton (1994).

${ }^{32}$ Fractal Analytics (2003).

${ }^{33}$ Thomas (2000), pp. 149-172.
} 
For example, the existence of scores reduces the incentive of lenders to assess the data in the credit register where his main motive is the automatisation of decision making. This is usually the case for most of small/middle sized credit.

A problematic aspect is the lack of transparency in the scoring process. The methodology is usually not disclosed, while it is not clear who has access to the scoring data. Scoring makes the credit data more tradable. It could thus be seen as tipping the conflict of interest between the prevention of overindebtedness vis-à-vis sales acceleration towards the latter.

For the problems that it raises, previous scholarship has pointed out the need of addressing consumer rights and transparency in the credit scoring of consumers. ${ }^{34}$ From this perspective, to some extent Germany has been a precursor in enacting specific legal measures. For the first time in Germany and largely in the EU, the law altering the German Data Protection Act of 29 May 2009 deals specifically with consumer-related scoring. ${ }^{35}$ In turn, the German Supreme Court (Bundesgerichtshof) has confirmed that credit scoring qualifies for meeting legal requirements under data protection legislation, but it has affirmed that the underlying mathematical and statistical calculation method can be protected as a trade secret. Thus, it remains open to question to what extent transparency can be guaranteed to consumers, which is a matter now under the consideration of the German Constitutional Court. $^{36}$

\section{Securitisation}

Information pooling and sharing can be used for the securitisation on lenders' portfolios of consumer loans, including mortgages.

In its simplest form, securitisation is a financial operation used by a financial institution on the receiving end of credit repayments from customers who have taken out financing. It bundles its loans repackaging the monthly loan payments into securities rated by rating agencies, and it backs them using the underlying loans as collaterals. It then transfers or sells such securities on to investors in order to receive funding which can be used to issue more loans.

According to financial theory, investors in asset backed securities need information on the quality of the underlying assets. Without such information, investors would not risk investing or they would require a risk premium which would signify higher refinancing costs for lenders, ultimately being passed on consumers with higher borrowing costs. Therefore, financial institutions involved in the process of securitisation avail themselves of the services of credit rating agencies such as Standard \& Poor's, Moody's and Fitch (only to mention the three big rating agencies that dominate the market and take the titles in the media) which grade or score the repackaged loans on the credit risk associated with those securities. In such rating of securities for the calculation of the risk of default, the agencies need to rely on data on the underlying loans from the information providers organising the exchange of information among the competing lenders. However, they do not have access to the data and they

\footnotetext{
${ }^{34}$ Ferretti (2009).

${ }^{35}$ Metz (2012).

${ }^{36}$ See Bundesgerichtshof, press release available online at http://juris.bundesgerichtshof.de/cgi-bin/rechtsprechung/document .py?Gericht=bgh\&Art=en\&sid=2ef8cefa03b7d0493f54c1bc71 ee0a53\&anz=1\&pos=0\&nr=66583\&linked=pm\&Blank=1. Schufa, Germany's leading credit bureau was sued by a German individual over the lack of transparency of its credit scoring methods. The plaintiff had been denied credit and Schufa had already provided him with information as required by law. However, the company did not provide the underlying method, which it regarded as a trade secret. The court held that while credit bureaus must disclose all personal data as prescribed in the Federal German Data Protection Act, they do not have to disclose how the underlying scoring algorithm weighed the various factors and how the reference groups used to arrive at a credit score were comprised. Following to this decision of the Supreme Court, the matter has been brought before the German Constitutional Court and a decision is awaited as to the balancing of the fundamental rights of privacy and data protection vis-à-vis the safeguard of trade secrets (German Constitutional Court, Case n. 1 BvR 756/2014)
} 
need to rely on the credit score assigned by the same information providers. ${ }^{37}$ Thus, the whole process mostly relies on a double scoring or rating from different intermediaries.

Securitisation has the effect of transferring credit risks to investors, releasing lenders from concerns over defaults, and ultimately resulting in more reckless credit for consumers as well as dangers for the health and stability of the financial system. Securitisation was pointed as one of the biggest factors contributing to the subprime lending boom and bust which generated what is known as 'the great financial crisis' that erupted in 2008. This discussion, however, is beyond the scope of this contribution and it has been analysed elsewhere in great detail. ${ }^{38}$

\section{Identity verification}

Traditionally, undertaking the identity check of an applicant has involved lenders requiring individuals to produce documentary evidence, such as a passport, an identity card, a driving licence, or in countries like the United Kingdom even utility bills. Such documents, then, were examined by a lender's officer in order to establish that documents were genuine and they truly related to the individual making the application. Officers, finally, needed to take the evidence of the identity check by photocopying and filing the documents.

The use of databases is said by the industry to enable lenders to check on several sources, thus forming the so-called 'electronic footprint' of every individual, which is used to match against the personal data supplied by the applicant.

In a way, identity verification challenges the role of the State, which is the only one which can determine the identity documents and true identity of individuals. Once more, cost saving is the main drive for such an additional use. But in those countries where such tools are used, the cost of credit does not appear to be lower for consumers (e.g. France and Belgium). ${ }^{39}$

\section{Marketing}

Credit data are increasingly used to segment and classify customers, and to price loans accordingly. Yet, those consumers who are a higher risk in the terms of the credit industry are those who pay more for credit. This is certainly not a use for the pursuit of responsible lending policies and overindebtedness prevention. A trend, for example, is that of setting-up businesses whose core activity is that of lending at higher rates to borrowers with poor credit records, also known as 'subprime lending'. ${ }^{40}$

Credit data are also used for marketing other banking products. Many private Credit Bureaus do not have pre-defined and strict conditions under which the data may be checked (e.g. request of the consumer for a credit offer, payment difficulties, etc.). And, even more important, one of the main use of scores is that they can be sold to other goods/services providers.

Other marketing activities resulting from the use of data are product development for the profitability of the industry and geo-marketing. ${ }^{41}$

\footnotetext{
${ }^{37}$ European Commission (2009); Keys, Mukherjee, Seru, and Vig (2008); Engel and McCoy (2011).

${ }^{38}$ E.g., for a detailed account of the securitisation of consumer loans see Engel and McCoy (2011).

${ }^{39}$ See, for e.g., Eurobarometers available from http://ec.europa.eu/public_opinion/archives/ebs/ebs_321_en.pdf; http://ec.europa.eu/public_opinion/archives/ebs/ebs_355_en.pdf.

${ }^{40}$ E.g. see in the UK CallCredit at http://www.callcredit.co.uk/products-and-services/consumer-marketingdata/segmentation-analysis. For some literature, see e.g. Engel and McCoy (2011).

${ }^{41}$ E.g. see the websites of the major Credit Bureaus such as Experian at http://www.experian.co.uk/marketing-services/index.html, Equifax at http://www.equifax.com/consumer/marketing,
} 


\section{Fraud prevention}

Consumer credit data can be used alongside the application processing systems to compare a current credit application with previous ones over a number of years by matching the application details. Thus, it would be possible to look for discrepancies and detect omissions, the data an applicant would like not to disclose, or inaccurate or untrue details within the applicant's history. Similarly, these databases would be used to detect multiple applications in the applicant's name within the same timeframe, misleadingly including consumers shopping around for quotes, or the use by the applicant of different names for the same banking details or other patterns of (alleged) fraudulent behaviour.

Databases, in this way, become substitutes of lengthier and more complete documentation in the interest of the credit industry. However, empirical evidence of the incidence of fraud vis-à-vis all loan applications is largely missing, as it is evidence that credit databases are the appropriate tool to prevent it. Arguably, further research in this area is necessary. If anything, reliance on databases erodes the principle of 'know your customers', where it means acquiring a proper and more individualized knowledge of customers.

\section{Fight against identity theft}

There are two most commonly known types of identity theft: (i) 'account takeover' occurs when the fraudster acquires someone else's credit account information and purchases products and/or services using that person's existing accounts. Victims normally learn of the account takeover when checking their account statements; (ii) 'application fraud' occurs when the impostor uses someone else's identifying information to open new accounts in that person's name. In this case, victims usually do not learn of the fraud for some time as the account statements are normally mailed to addresses used by the identity thief and there is no record on the accounts effectively in use.

Thus, databases can be used as real-time identity fraud detection and prevention automated tools, by matching key personal data provided on credit applications by real-time access into a range of powerful market leading data sets, including directories and other independent data sources. ${ }^{42}$

The credit industry believes that the practice described above may prevent the 'account takeover' type of identity theft.

In the fight against 'application fraud', by contrast, the use of credit reports requires the active involvement of customers. Thus, a number of Credit Bureaus have seized the opportunity to develop a new business to the consumer market by offering credit reports for a fee, thus allowing and encouraging individuals, who are motivated by their anxiety, to check their own report regularly and catch possible frauds committed at their name. ${ }^{43}$

By contrast, it can be argued that increasing reliance on databases increments identity theft and makes it possible. Moreover, because of the reliance on databases, consumers who fall victim of identity theft have to go through hurdles to have their files cleaned and suffer the consequences of the theft for long time.

\section{Emerging uses: job applications, tenancies, and uses in other economic sectors}

Credit data all the time more become the gateway for other economic sectors such as telecoms or utilities. In some jurisdictions, such as in the UK, credit data are used by estate agencies and landlords 
for granting tenancy agreements. Similarly, such data may now be used to screen job applicants. Consumer credit data, therefore, risk becoming increasingly more a tool of economic and social inclusion or exclusion.

\section{New consumer services}

A number of commercial credit bureaus have developed services for consumers, selling them the credit report to verify if they can qualify for credit and the amount that they may be able to obtain. ${ }^{44}$

However, concerns have been expressed that the credit reports sold to consumers are not the same as those sold to financial institutions, where they have at their disposal much more data, detail, and in depth. In the end, consumers do not buy what the credit industry really uses. ${ }^{45}$

In this way, the credit data system has created new needs for consumers to know if and how they qualify for credit, and how financial institutions value them. This may have the potential to nudge consumers towards the financial behaviour envisaged by the credit industry.

However, it is questionable to what extent it is legitimate or appropriate to sell information to consumers about themselves. Under Data Protection Law, as implemented in the national laws of the Member States, data subjects (i.e. consumers) have the legal right to access data regarding themselves. With the emerging provision of this kind of services the credit data industry may be selling what in fact is a right of access, which by law is usually free of charge or, in the UK, it costs a minimal fee of 2 GBP.

\section{Type of data used}

The detail of the source and type of information collected and disseminated by Credit Bureaus varies from country to country. In general terms, however, it may be synthesised that Credit Bureaus store, process, and disseminate consumers' files containing data on their previous and existing accounts, which normally include detailed information about mortgages, bank accounts, store cards, charge cards, credit cards, loan accounts, and in many jurisdictions even mail order accounts as well as telecom and other utilities accounts.

An important distinction to be drawn when referring to the type of data collected and distributed by Credit Bureaus is the one between the so-called 'negative' information and 'positive' information.

'Negative' information usually refers to negative consumer data, (information about defaults on payments, delays, delinquencies, bankruptcies etc.). That is, information with a negative connotation on the payment history and the financial behaviour of the data subject.

'Positive' information, by contrast, refers to positive consumer data, i.e. information about the financial standing, payments and other details which do not indicate a default or a late payment.

\footnotetext{
${ }^{44}$ See, for example, the website of Experian at http://www.experian.co.uk/consumer/

${ }^{45}$ E.g. see Consumer Financial Protection Bureau (2012)
} 
Attempts have also been made to classify semi-negative or semi-positive information, which would refer to data on accounts which demonstrate some signs of problems but have not yet proceeded to the state of being 'negative', i.e. accounts which are in acceptable time arrears with no warning to the customer being yet issued by the lender. ${ }^{46}$

At EU level, there is no commonly accepted use of the type of information. Some countries make use of both positive and negative information while others prescribe that only negative information can be used. In extreme cases, in some countries non-credit data are also used (e.g. the UK), while on the other extreme in some countries the use of positive data is unconstitutional (e.g. see France). ${ }^{47}$

Another major problem at EU level is that there is no uniformity or common understanding regarding the terminologies used and the breadth of information.

Each file may contain the name of the borrower, his/her date of birth, current address, previous addresses if any, linked addresses, marital and employment status, number of accounts, amounts, types, stage (loan under approval, withdrawn, denied) and terms of the accounts, amount of monthly instalments, amount of residual instalments, historical data, number of defaults, amount of arrears, name of granting institutions, payment history (both regulars and in default), dates. In addition, most of the time, information relating to people that have a financial relationship with him/her are included (including, but not limited to, credit warrantors). ${ }^{48}$

Each personal file, then, usually has status codes assigned to it by the lender, showing whether it is up to date, in arrears, by how much in arrears, if the account is in default and how many times the repayment has been late. Closed accounts show the status codes for a variable amount of time prior to closure. $^{49}$

A survey carried out by the World Bank indicates that a large majority of Credit Bureaus worldwide also collect information on taxpayer IDs $(75 \%)$, loan rating data $(70 \%)$, and type and value of collateral used to secure loans (around $50 \%$ ). ${ }^{50}$

In many cases, on the consumer's credit files there is also a record of the searches, including the dates and the reason for the search.

In addition, Credit Bureaus normally collect and make use of 'public record information' obtainable by law from public sources to integrate each consumer's file.

Such information usually includes data from the following sources (which most of the times are not visible or are known to consumers):

\footnotetext{
${ }^{46}$ Howells (1995), pp. 343-359, sp. 344.

47 See Conseil Constitutionnel, Décision n. 2014-690 DC du 13 mars 2014. In 2010 France proposed legislation implementing the EU Consumer Credit Directive 2008 recommending a positive credit reporting system operated by the Bank of France. It was included within the loi Hamon which introduced a number of consumer protections. However, the relevant provisions on the establishment of a positive credit database were referred to the Constitutional Court (Conseil Constitutionel) which declared them unconstitutional as a disproportionate intrusion on the constitutional right of privacy which was not outweighed by possible benefits related to credit decision-making.

${ }^{48}$ See for example Credit Report, Equifax, from https://www.econsumer.equifax.co.uk. See also credit reports from Experian from http://www.experian.co.uk; CallCredit, from http://www.callcredit.co.uk; CRIF, from http://www.crif.com

49 Ibid. In the UK, for example, such amount of time extends up to three years.

${ }^{50}$ Miller (2003 b), sp. 43.
} 
1. the electoral or voters' roll, as well as other national directories (which are used to match the address on it with the address provided in the current and previous applications, thus verifying in addition how long the applicant has lived at a given address for);

2. National or county court judgements or decrees (as the case may be) entered for sums of money in the courts or other competent authorities in the relevant country - in most cases Credit Bureaus are informed about judgements as soon as they are entered by the courts;

3. bankruptcies;

4. court administration orders. $^{51}$

In some European jurisdictions Credit Bureaus' databases may also contain in the file of an individual information about one or more persons other than the relevant individual. The circumstances in which information about another person(s) may appear on someone's credit reference file relate to situations where:

1. the name(s) is(are) the same or similar and the address is the same;

2. the Credit Bureau knows beforehand that such other person(s)' information applies to such individual;

3. those other person(s) has(have) the same surname as such individual and they have been living at the same time either at the current or at any other previous address contained in such individual's file (this aggregate information enables Credit Bureaus to include information on the applicant about family members and their payment history). ${ }^{52}$

It is worthy of note that it is the duty of the individual to request the Credit Bureaus to eventually create a dissociation if a financial connection does not in fact exist.

Table 1 shows the type of information and operations in the Member States of the EU. It exposes a great difference in the type and usage across the EU and a jeopardised infrastructure at EU level.

Table 1 - Source: European Parliament (2011); European Commission (2009).

NB: The Table below should be corrected as regards Romania. CBs operations: there are operations for creditors only (not for other service providers - telecom, gas, water companies, etc.). But in the category of creditors there are not only banks, but also non-banking lenders.

Also note that Ireland is underway in establishing a Public Credit Bureau leaving an open question as regards the future to private sector credit bureaus.

The name and website of the Credit Bureaus in each country is available from the credit information trade association 'Association of Consumer Credit Information Suppliers' (ACCIS) at http://www.accis.eu/membership/list-of-fm.html

51 Credit Report, Equifax. See also UK Information Commissioner's Office, "Credit explained", at https://ico.org.uk/Global/ /media/documents/library/Data_Protection/Practical_application/credit-explained-dpguidance.pdf

${ }^{52}$ See for example in the UK CallCredit www.callcredit.co.uk; Experian www.experian.co.uk; Equifax www.equifax.co.uk. 

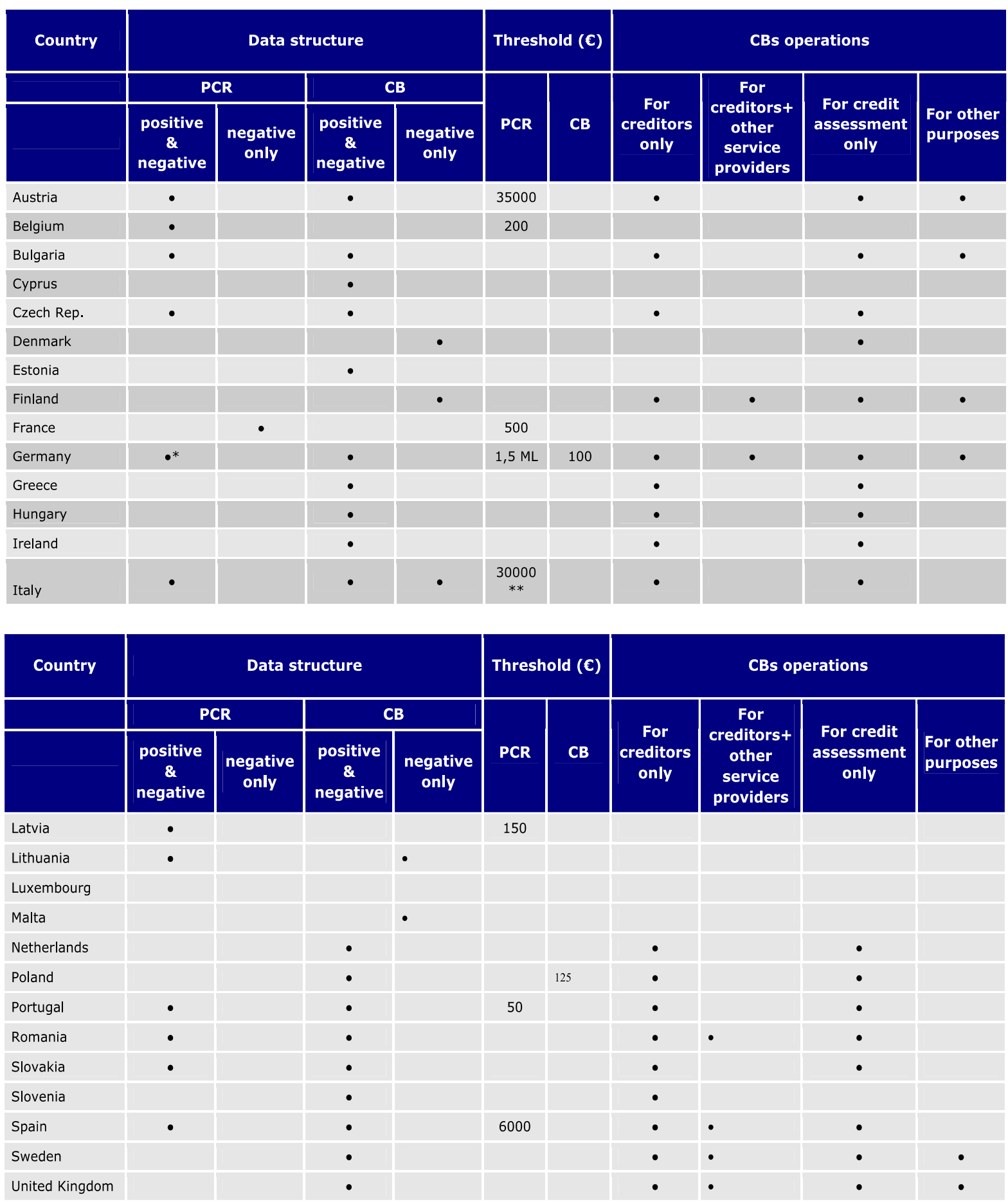

Note: *Does not cover consumers, ${ }^{* *}$ No threshold applies to bad debts

\section{The legal form and functions of credit bureaus in the $\mathbf{E U}$}

Credit bureaus now exist in all EU Member States with the exception of Luxembourg, but their legal form or institutional structure varies depending on different policy or other objectives, and the function that they perform in the economy and society. Databases are organised and the types of information are provided depending on the pursuit of defined policy objectives or other private interests that they are meant to address. The different role of credit information providers reveals a key distinction between public and private or commercial organisations. While the former is normally a 
part of a national central bank or supervisory authority, and institutionally and legally designed to address the stability of the financial system and the monitoring of the indebtedness of consumer households, the latter offers to the market risk-management and market intelligence tools to enhance economic efficiency and the profitability of financial institutions irrespective of whether these are banks lending the money of depositors or any other entity doing business through the provision of credit in return for profit. ${ }^{53}$

\section{Private or commercial credit bureaus}

These are fully-fledged privately owned companies working for profit (see e.g. commercial companies in the UK, Germany, Italy) or for the benefit of banks (see e.g. not for profit entities designed to make the interest of commercial ventures such as banks in Slovenia or Poland) that are no more controlled, monitored, or influenced by State-controlled organisations or other public bodies than any other privately owned organisation or business. Nor are they accountable to public bodies, central banks, or other financial service regulators. They are subject to the same rules and regulations as every business in the marketplace. Their job is to provide services to the financial services industry compiling databases. Even looking at the websites of these companies, they clearly state that they provide decision-making tools or marketing intelligence to the credit industry. They do not claim social tasks to prevent consumer over-indebtedness and they do not hold accountable for the decisions taken by the credit industry.

They can have a broad range of client members depending on the jurisdiction, from banks to non-bank lenders. In addition to traditional financing firms that are not banks, other less obvious examples may include telecommunication companies, utility companies, mail order companies, and/or any other business advancing goods or services to consumers paying for them at a later stage. Consultation of their databases is not mandatory by law prior to the underwriting of credit and is carried out on a voluntary basis (the exception is Slovenia where banks have to use such bank-owned database, but other non-bank lenders are not obliged to subscribe to it). As participation by lenders in a privately owned consumer credit information system is not compulsory, the rules relating to the functioning of the system are not imposed by law or regulation but are governed by contract law. ${ }^{54}$

In some jurisdictions, these databases are supplemented with non-credit data collected from other sources. Thus, financial and non-financial entities may have access to consumer information across different economic segments. In this way, accessibility to full credit and other non-credit data may affect the inclusion, exclusion, or sorting in different economic spheres of the consumers. Moreover, this leads to the problem of incomplete or missing data in one's credit profile, possibly resulting in an inaccurate picture on the consumer's finances and wrong scoring assumptions. This is a problem unique to private credit registers. As commercial ventures, they integrate their services with consumer risk scoring (which includes both behavioural and sociological customer scoring), loan or mortgage rating, risk screening, monitoring, propensity modelling, debtor tracking, and support to debt collection.

\section{Public credit bureaus}

These are institutions typical of continental Europe, where they first originated and developed with the objective of providing an information system for supervisors to analyse banks' portfolios and monitor the health and soundness of the overall financial system of a country, as well as the level of indebtedness of borrowers, both legal and natural persons.

\footnotetext{
53 Jappelli and Pagano (2000); Jappelli and Pagano (2003), pp. 81-114, Jappelli and Pagano( 2006), pp. 347-371; Ferretti (2008).

${ }^{54}$ Ferretti (2008).
} 
Generally, they exercise a public function by furthering the general stability of the banking and payment system.

This requires the monitoring of the safety and soundness of banks, which includes the monitoring of the amount of exposure of each bank towards legal persons and individuals who, consequently, undergo checks over their levels of indebtedness.

Only banks participate in the system and are subject to the underlying rules, unlike private registries that are conceived as open systems with the incentive of bringing an increasing number of subscribers and information into play. ${ }^{55}$

Another key difference is that financial institutions that are under the supervision of a country's central bank or supervisory authority are required to report certain credit data on a regular basis by law or other regulation. As participation in the system is compulsory, its rules are imposed by law or regulation and not under contract. This compulsory nature also means that public bureaus have complete coverage of the financial institutions of a country, and no bank lenders are left out as may happen when parties are free to negotiate whether to take part in a system or not, or which system to be part of if more than one exists. ${ }^{56}$

Equally, public authorities have a legal basis for demanding that reporting lenders remedy possible inaccuracies or make available missing data. Failure to comply can result in sanctions that may be imposed by law, such as penalty fees followed by supervisory actions. ${ }^{57}$

It is undisputable from all the features discussed above that private or commercial Credit Bureaus on the one side, and public Credit Bureaus on the other side cannot be reciprocally substitutes to the extent that the latter exercise functions in the public interest that the former are not entitled and do not perform. Public providers, however, can substitute for private/commercial ventures to the extent that the lenders' debt provisioning remains tightly controlled and the amount of overdue or defaulted debt is controlled. Lenders are entitled and do use these databases for risk-management purposes.

In the end, as Tables 2 and 3 show, the picture in the EU is fragmented. There are profound differences in the legal form and structure in the various Member States, the different roles of credit bureaus, and the various types of data exchanged. The Tables summarise the above discussion of the legal form of credit bureaus in terms of private versus public ownership and function. In the case of private or commercial credit bureaus, it emerges clearly the self-interest pursued by the credit industry and the bureaus. On the contrary, the goals, role and function of databases controlled by public authorities show the pursuit of the general interest.

\footnotetext{
55 Jappelli and Pagano (2003); Ferretti (2008)

${ }^{56}$ Ibid.

${ }^{57}$ Miller (2003 b), pp. 25-79.
} 
Table 2 - Legal form and structure of credit bureaus in the Member States of the EU

Source: European Parliament (2011); European Commission (2009).

NB: The Table below should be corrected as regards Romania. The number of private Credit Bureaus is 1 (instead of 2), and the ownership structure is $>50 \%$ ownership by creditors - in fact it is $100 \%$ (instead of $<50 \%$ ownership by creditors). Ireland is underway in establishing a Public Credit Bureau leaving an open question as regards the future to private sector credit bureaus.

\begin{tabular}{|c|c|c|c|c|c|c|c|}
\hline \multirow[t]{2}{*}{ Country } & \multirow[t]{2}{*}{$\begin{array}{c}\text { Public credit } \\
\text { register }\end{array}$} & \multicolumn{3}{|c|}{ no. of private Credit Bureaus } & \multicolumn{3}{|c|}{ Ownership structure } \\
\hline & & For profit & $\begin{array}{c}\text { Not for } \\
\text { profit }\end{array}$ & $\begin{array}{c}\text { Not ownership } \\
\text { by creditors }\end{array}$ & $\begin{array}{c}\leq 50 \% \\
\text { Ownership by } \\
\text { creditors }\end{array}$ & $\begin{array}{c}>50 \% \\
\text { Ownership by } \\
\text { creditors }\end{array}$ & Other \\
\hline Austria & Yes & & 1 & & & & 1 \\
\hline Belgium & Yes & & & & & & \\
\hline Bulgaria & Yes & 1 & & 1 & & & \\
\hline Cyprus & No & 1 & & & & 1 & \\
\hline Czech Rep. & Yes & 1 & & & 1 & & \\
\hline Denmark & No & 2 & & 2 & & & \\
\hline Estonia & No & 1 & & 1 & & & \\
\hline Finland & No & 1 & & 1 & & & \\
\hline France & Yes & & & & & & \\
\hline Germany & Yes & 1 & & & 1 & & \\
\hline Greece & No & 1 & & & 1 & & \\
\hline Hungary & No & 1 & & & 1 & & \\
\hline Ireland & No & 1 & & & 1 & & \\
\hline Italy & Yes & 2 & 1 & 1 & & 1 & 1 \\
\hline \multirow[t]{2}{*}{ Country } & $\begin{array}{l}\text { Public credit } \\
\text { register }\end{array}$ & \multicolumn{3}{|c|}{ n. of private Credit Bureaus } & \multicolumn{3}{|c|}{ Ownership structure } \\
\hline & & For profit & $\begin{array}{c}\text { Not for } \\
\text { profit }\end{array}$ & $\begin{array}{l}\text { Not ownership } \\
\text { by creditors }\end{array}$ & $\begin{array}{c}\leq 50 \% \\
\text { Ownership by } \\
\text { creditors }\end{array}$ & $\begin{array}{c}>50 \% \\
\text { Ownership by } \\
\text { creditors }\end{array}$ & Other \\
\hline Latvia & Yes & & & & & & \\
\hline Lithuania & Yes & 1 & & & & 1 & \\
\hline Luxembourg & No & & & & & & \\
\hline Malta & No & 1 & & & & 1 & \\
\hline Netherlands & No & 1 & 1 & 1 & & & 1 \\
\hline Poland & No & 1 & & - & 1 & - & \\
\hline Portugal & Yes & 2 & & & & 1 & \\
\hline Romania & Yes & 2 & & 1 & 1 & & \\
\hline Slovakia & Yes & 2 & & 1 & 1 & & \\
\hline Slovenia & Yes & & 1 & & & & 1 \\
\hline Spain & Yes & 2 & & 1 & & 1 & \\
\hline Sweden & No & 6 & & 5 & 1 & & \\
\hline United Kingdom & No & 3 & & 3 & & & \\
\hline
\end{tabular}


Table 3 - Role and structure of private/commercial and public credit bureaus

Source: European Commission (2009)

\begin{tabular}{|c|c|c|}
\hline & Credit Bureau & $\begin{array}{l}\text { Public Credit Register } \\
\end{array}$ \\
\hline Ownership structure & Private/commercial entity & Central Bank or Supervisory Authority \\
\hline Clients structure & $\begin{array}{l}\text { Mainly creditors but sometimes also } \\
\text { other services providers }\end{array}$ & Financial institutions authorised to grant credit \\
\hline Scope & Credit assessment and monitoring & $\begin{array}{l}\text { - Banking supervision, building statistics, } \\
\text { financial stability studies } \\
\text { - Monitoring and preventing over-indebtedness } \\
\text { - Credit assessment } \\
\text { - Fostering credit institutions prudent } \\
\text { management }\end{array}$ \\
\hline $\begin{array}{l}\text { Creditors' } \\
\text { participation }\end{array}$ & Generally voluntary & Mandatory by law \\
\hline $\begin{array}{l}\text { Principle of } \\
\text { reciprocity/Non } \\
\text { discriminatory access }\end{array}$ & Yes & Yes \\
\hline Type of data stored & $\begin{array}{l}\text { - Full credit data (positive and negative } \\
\text { data) } \\
\text { - Often also non-credit data }\end{array}$ & $\begin{array}{l}\text { - Credit data from financial institutions } \\
\text { authorised to grant credit (including both } \\
\text { positive and negative data in a majority of } \\
\text { cases) } \\
\text { - Data on bankruptcy of natural and legal } \\
\text { persons }\end{array}$ \\
\hline $\begin{array}{l}\text { Additional services } \\
\text { provided to creditors }\end{array}$ & $\begin{array}{l}\text { Mainly: } \\
\text { - Credit scoring based on the whole CB } \\
\text { dataset } \\
\text { - Software applications } \\
\text { - Portfolio management services } \\
\text { - Fraud prevention systems } \\
\text { - Authentication products... } \\
\end{array}$ & None \\
\hline Use of thresholds & Yes, but generally low & Yes \\
\hline $\begin{array}{l}\text { Degree of detail of } \\
\text { the information } \\
\text { provided }^{17}\end{array}$ & $\begin{array}{l}\text { Detailed information on each individual } \\
\text { loan. In some countries, credit } \\
\text { information merged with other data (e.g. } \\
\text { from public sources). }\end{array}$ & $\begin{array}{l}\text { Information sometimes in a consolidated form } \\
\text { (giving the total loan exposure of each } \\
\text { borrower). In some PCRs, (Belgium, Italy, } \\
\text { Portugal or Spain), the information is also given } \\
\text { in a detailed form. }\end{array}$ \\
\hline Coverage & $\begin{array}{l}\text { Depends on the legislation, length of } \\
\text { service provided, financial culture, etc. }\end{array}$ & Universal coverage \\
\hline
\end{tabular}

\section{Reliability and proportionality of data to achieve policy objectives}

As shown above, the exchange of consumers' financial information and the use of centralised databases may be regarded not only as a risk management tool but also a form of creditworthiness assessment to identify the over-indebtedness of individuals.

If on the one hand this point of view may support an argument for the exchange of information in the general interest of consumers, on the other hand it remains open to debate whether the design of databases is proportionate to the policy goals to be achieved, and whether the type and the level of aggregation or detail of information exceeds the purpose for its sharing.

It is argued that extensive, expansive or indiscriminate use of data is disproportionate to the policy goals to be achieved. Only negative data in aggregate form may provide a partial picture of the consumer financial exposure and their state of financial difficulty. 
At the same time, the sharing of credit data raises debates over social duties and social responsibilities of the credit industry or private credit bureaus as social actors, prudential supervision, and the institutions which should be entrusted with the exercise of such a social function.

The credit industries, as well as the private and commercial credit bureaus, are not social actors or institutions designed to work in the public interest. They are commercial or private entities whose mission is to make the interest of shareholders and generate profits or, when not-for-profit in the context of banking associations, they are designed to make the interest of the associated commercial ventures. In these cases there would be a conflict of interest which prevents possible arguments that they may work in the interest of consumers. ${ }^{58}$ The picture may be different when public institutions are involved.

Moreover, the capability of credit data to prevent future over-indebtedness is questionable. Credit data sharing cannot foresee the real causes of over-indebtedness. Life time events such as illness, divorce, job losses, etc. and/or poor market conditions in the economy are the major causes of consumer failure to repay debts timely or over-indebtedness. ${ }^{59}$ These situations cannot be caught or resolved by credit data and their exchange. All what data may do is the abstract representation of unique or circumstantiated situations without distinguishing the causes, and they retrieve and give a memory to such representations that become accessible to all other market players, thus inter alia raising doubts as to their ability to predict whether the same consumer will repay loaned money in the absence of those life-time events that once originated the data themselves.

Arguably, moreover, giving a second chance to consumers may well be in the consumer interest and it may even be economically efficient. In this context, a second chance is intended as not retrieving information which could have negative consequences on consumers, especially under those circumstances that are not tied or linked with the original negative information. The same may be put forward for the case of personal insolvencies under the law of the Member States in order to avoid the perpetration of the stigma attached to such procedures. ${ }^{60}$

The examples of countries where only public credit bureaus exist such as Belgium and France (where inter alia only negative data are allowed) question the role and effectiveness of private credit bureaus. In these countries, for example, the levels of consumer over-indebtedness are not higher than in the other Member States where there is an extensive sharing of consumer data. ${ }^{61}$

Likewise, in these two Member States the cost of credit for consumers does not appear to be higher than in other Member States. ${ }^{62}$

58 There are considerable differences in size, turnover, volume of activities and public engagement of credit bureaus across Europe. Some credit bureaus engage in social activities of financial education or other socially helpful activities. All the same, the duty of commercial credit bureaus is towards their shareholders and socially helpful activities remain within the sphere of publicity or enhancing their commercial reputation.

${ }^{59}$ Ramsay (2007), sp. 578-580; Caplovitz (1963); Adler and Wozniak (1980); Berthoud and Kempson (1992); Hoermann (1986); Elliott (2005); Balmer, Pleasence, Buck, and Walker (2006), pp. 39-51; Dominy and Kempson (2003).

${ }^{60}$ Personal Insolvency Laws in the EU raise difficult issues and questions that are beyond the scope of this work. For a thorough discussion, see e.g. Micklitz (2012), Ramsay (2012 a), Niemi (2012)

${ }^{61}$ See Civic Consulting (2014).

${ }^{62}$ See, for e.g., Eurobarometers available from http://ec.europa.eu/public_opinion/archives/ebs/ebs_321_en.pdf; http://ec.europa.eu/public_opinion/archives/ebs/ebs_355_en.pdf.

For literature comparing the use of consumer credit in France and in the UK see Ramsay (2012 b). Trumbull (2014) puts forward that America's credit culture emerged from an evolving coalition of lenders seeking to make their business socially acceptable and NGOs that pushed the idea of credit as welfare-enhancing and promote labour and minority rights. By contrast, the author argues that in France, where a similar coalition did not emerge, consumer credit continued to be perceived as economically regressive and socially risky. 


\section{Cross-border exchange of data and integration of credit markets}

As seen earlier, the CCD and the MCD provide that foreign lenders shall not be discriminated in the participation in such a system.

However, unfair or discriminatory access conditions for foreign lenders may take place in more circumstances. Foreign lenders may be newly set-up institutions establishing a physical presence or institutions that establish a branch in another Member State. But, at EU level there are other emerging modes of providing credit which are necessary for market integration. Other possible forms of market integration in the sector are the cross-border provision of services, including internet banking or ecommerce, where lenders are based in one Member State and do business with consumers in another Member State.

Also, Europeans are becoming increasingly mobile under the free movement of persons rights.

In principle, however, under the current system non-established financial institutions do not have access to all existing credit bureaus in the EU and they would not be able to provide information to all of them any time they establish a financial relationship with a consumer.

This is because lenders from a Member State are unlikely to have or establish an ongoing contractual relationship with a private or commercial credit bureau in another Member State.

Moreover, the business model of reciprocity would prove hard to satisfy, where foreign lenders would be in the impractical situation to provide their data portfolio to the credit bureau of another country, in addition in the type and breadth of data required by such a different system. At the same time, in a commercial environment, the existing national participants may be averse to share their data portfolios with foreign players and allow competition on their market from abroad on a basis that is not reciprocal.

The MCD is of little help in this respect, as it recognises that "access conditions, such as the costs of accessing the database or requirements to provide information to the database on the basis of reciprocity should continue to apply. Member States should be free to determine whether, within their jurisdictions, credit intermediaries may have access to such databases". ${ }^{63}$

Likewise, in the case of public credit bureaus, foreign lenders do not have to abide by the national rules of another Member State if not physically established there (provided they qualify as 'banks').

Finally, credit bureaus across the EU make use of different type of information, which makes the exchange within the EU not possible.

If EU law provides for the integration of credit markets via the CCD and the MCD, on the other hand the underlying information markets have remained national, which risk rendering the provisions of EU law ineffective in practice. The CCD and the MCD are likely to be prevented from enhancing crossborder credit, either as cross-border provision of services, consumer consumption abroad, or EU migration and access to host member state services. If foreign lenders are allowed to consult databases on a non-discriminatory basis but there remain barriers for a European exchange of information, information markets will remain jeopardised into national markets and the underlying credit markets will be prevented to integrate.

\section{Competition in the credit information industry}

As noted in Section 2.1.4., traditionally consumer credit information exchanges are looked vis-à-vis the competitive or anti-competitive object or effect on those making use of the information in the market for consumer loans, not on those providing information.

\footnotetext{
${ }^{63}$ Recital 60 of the MCD.
} 
Clearly, there is the element of the competition among lenders; yet, this involves not only the covered horizontal relations between the lenders themselves, but also the vertical relation between the lenders and the credit bureaus. Moreover, when commercial entities are involved, horizontal competition between information providers may become relevant.

However, to the extent that information is turned into a tradable commodity of commercial value, competition issues have not yet been addressed. ${ }^{64}$

Traditionally, information exchanges among competitors have been treated as 'hub and spoke' agreements. These are ordinary vertical agreements but with potential horizontal anti-competitive effects. Precisely as in the case at study, they involve an exchange of information between two or more undertakings operating at the same level of the production or distribution chain (i.e. the lenders) via a common contractual partner operating at a different level of the chain (i.e. the credit bureau) ${ }^{65}$

But, as outlined earlier in this work, information providers become active market players, especially when private commercial actors are the suppliers, influencing and impacting on the underlying consumer markets in terms of lenders' entry and behaviour, transparency, pricing of loans, and consumers access to financial services.

Some economic literature has already shown awareness of anti-competitive problems relating to such a vertical or hub-and-spoke relationship in consumer financial markets beyond the traditional analysis: it has been demonstrated how credit bureaus may well be used by dominant lenders as concerted practices to raise rivals' costs either downstream for new market players, or upstream for possible rival credit bureaus that cannot obtain data from lenders. ${ }^{66}$

This is what happens in several EU Member States where only one credit bureau at national level pools consumer financial data, ${ }^{67}$ which risks having the undesirable effect of financial institutions becoming vertically integrated with one credit bureau, often of commercial nature. This is so because participation, coverage and accuracy are intertwined in the same essence of an information system, which would not make any sense if incomplete, i.e. when participation and coverage are not universal, in turn translating into inaccuracy.

From this point of view, competition in the information industry within the EU is almost absent.

Whilst public authorities are exempted from this, it is an anomaly that commercial credit bureaus do not face competition in the relevant market of credit data, which remains at national level. Yet, the relevant market for credit for consumers is, or should be, the EU market.

Credit bureaus operate through a network structure. They are natural monopolies in that the extension of a system's coverage itself enhances its effectiveness. In fact, they are dependent on that network structures within which information is traded, where the participants that share the information constitute such a network. ${ }^{68}$

The achievement of economies of scale is essential for coverage, where scale and scope effects affect coverage which has the propensity to universality, thus concentration. Historically, for example, the need to achieve economies of scale with nationwide market coverage was the main reason behind the

\footnotetext{
${ }^{64}$ Ferretti (2014).

65 Odudu (2011).

${ }^{66}$ Giannetti, Jentzsch, and Spagnolo (2010).

${ }^{67}$ European Commission, "Report on the retail banking sector inquiry", Commission Staff Working Document accompanying the Communication from the Commission - Sector Inquiry under Art 17 of Regulation 1/2003 on retail banking (Final Report) [COM(2007) 33 final] SEC(2007) 106; European Commission (2009).

${ }^{68}$ Pagano and Jappelli (1993), pp. 1693-1718.
} 
concentration process that occurred in the US after an initial period of numerous credit bureaus spread over the nation's territory to serve local business communities. ${ }^{69}$

Economic research describes such networks as a form of industrial organisation and market governance, where they can influence market structure, and the behaviour of firms and their performance, hence competition. Accordingly, in credit reporting markets, the information flows among agencies, information suppliers and consumers constitute a network of information whose value increases as more lenders are connected to it. Consequently, the more the network of one credit bureau increases, the more attractive it becomes for potential participants or participants to other networks. Therefore, to the extent that scale and scope effects also affect coverage, the more sources are connected to the network, the more detailed becomes the credit report and knowledge, and the more precise may become for risk-management purposes. ${ }^{70}$

In short, the very nature of the consumer financial information business demands that the success of the system depends on its universal extension; otherwise it would be of little or no use.

Arguably, a new stream of research is necessary in this area. Competition law is usually investigated in the reference credit market but the market for consumer data (i.e. the market of information suppliers) is understudied. Also, in the area of information pertaining to consumers, many areas of law intersect one with the other. The relationship between competition law and its goals and the interest of consumers under consumer protection law need to be looked closer, especially in an area which is dominated by fundamental rights such as data protection law. ${ }^{71}$

\section{Consumer protection concerns beyond data protection: credit data as the gateway of the economic life of consumers}

Credit data sharing by commercial credit bureaus and the uses made by lenders raise questions of possible economic discrimination, classifications, sorting, standardization of behaviours and the need to build a financial CV as dictated by the industry. These issues may easily translate into inclusion or exclusion from mainstream financial services, and they have the potential of ultimately affecting the social sphere of consumers in addition to their dignity and liberty as human beings.

Also, credit data sanction or penalize failures to repay or repay late. But the large majority of consumers fail to repay their debts or pay them back late (with profitable interests for the industry) for the occurrence of events that are not predictable at the time of contracting a loan and that credit data cannot foresee. Poor macro-economic conditions, job losses, divorces, illnesses, family deaths cannot be anticipated but credit data give a memory to the system, penalizing consumers even further. ${ }^{72}$

Also, the idea that the conforming of behaviours may be dictated by the financial industry can be a worrying scenario for society. Consumers adapt their behaviours to what the industry demands, becoming aware that failure to play by their rules may translate in exclusion from mainstream services.

Moreover, it is questionable that also those who are not in the databases for not having a credit history may face negative consequences in the access of mainstream services, so that everyone becomes

\footnotetext{
${ }^{69}$ Olegario (2003), pp. 115-159.

${ }^{70}$ Jentzsch (2003); Jentzsch (2006).

${ }^{71}$ See Ferretti (2014).

72 On the causes of defaulting see e.g. Ramsay (2007), sp. 578-580; Caplovitz (1963); Berthoud and Kempson, (1992); Hoermann (1986); Balmer et al (2006); Dominy and Kempson (2003); Vandone (2009); Niemi (1999).
} 
tempted to build his/her financial CV for not becoming penalized at a later stage. This is what already happens in the US where the market is more mature than in the EU. ${ }^{73}$

The ultimate suggestion is that further research is needed to assess whether or to what extent credit data and the scoring of consumers act to exclude low-income, vulnerable, or non-conforming consumers from markets. As the use of credit data and scoring can turn into classification, categorising and sorting mechanisms, financially vulnerable consumers may be easily recognized, classified ad excluded. Until now, very little is known about the relationship between the use of consumers' data as a method of selection or credit pricing, as well as exclusion of those members of society who do not qualify under the standards set by mainstream lenders. For example, more knowledge is needed to understand the credit behaviour of those who are not eligible to take credit by mainstream lenders and have a poor credit rating retrieved by the data. To what extent are they likely to recourse to subprime lenders?

\section{Prospects for a EU standardisation and shared system of credit data}

At the proposal stage of the MCD the European Commission had included provisions that would have allowed to harmonise at least some key terms used in credit databases (terms such as 'defaults', 'arrears') and to define uniform credit registration criteria, as well as data processing conditions to be applied to credit databases (e.g. the registration thresholds), in order to increase reliability of information contained in databases, facilitate creditworthiness assessments and in the long-run promote cross-border supply of credit. But these provisions were not kept during negotiations and in the final text of the directive. ${ }^{74}$

Nevertheless, as outlined in Sections 7 and 8 above, the EU internal market and the integration of credit markets for consumers raise questions of how to measure over-indebtedness and assess household creditworthiness. Likewise, the establishment of a level playing field for the competition of financial institutions may demand that they are equipped with similar tools and no restrictions or barriers exist in the Member States. In turn, this means that credit-risk data may require standardisation or a harmonised measurement system for the EU and its market players. As shown earlier, however, this is far from being the situation of a jeopardised system of national credit data sharing.

This study has outlined that other public policy goals are associated with the use of credit data, especially as regards the databases operated by national central banks containing loan-level or borrower-level information to supervise the national financial system (Sections 1.2 and 5.2 above). Credit data also serve the purpose for statistical and economic analysis.

The free movement of capital and economic and monetary union within the EU demand for the adoption of an economic policy which is based on the close coordination of Member States' economic policies, on the internal market and on the definition of common objectives. Price stability, sound

\footnotetext{
${ }^{73}$ Mierzwinski and Chester (2013); Hendricks (2004)

${ }^{74}$ Commission adoption of a proposal for a Directive on credit agreements relating to residential property, $\operatorname{COM}(2011) 142$. The following provisions were deleted during the negotiations between the Council and the European Parliament:

Article 14(5) - "Powers are delegated to the Commission (...) to specify and amend the criteria to be considered in the conduct of a creditworthiness assessment as laid down in paragraph 1 of this Article and in ensuring that credit products are not unsuitable for the consumer as laid down in paragraph 4 of this Article".

Article 16(2) - "Powers are delegated to the Commission (...) to define uniform credit registration criteria and data processing conditions to be applied to the databases referred to in paragraph 1 of this Article. In particular, such delegated acts shall define the registration thresholds to be applied to such databases and shall provide for agreed definitions for key terms used by such databases".
} 
public finances and monetary conditions, and a sustainable balance of payments are goals of the EU to pursue its objectives set in Article 3 TEU. ${ }^{75}$

The European Central Bank (ECB) is the central bank in charge of Europe's single currency, monetary policy, and price stability alongside the European System of Central Banks (ESCB). ${ }^{76}$

In addition, on the basis of Article 127(6) of the Treaty on the Functioning of the European Union and of the Council Regulation (EC) No 1023/2013 (the "SSM Regulation") specific tasks concerning the prudential supervision of credit institutions established in participating Member States. It carries out these tasks within a Single Supervisory Mechanism (SSM) composed of the ECB and the national competent authorities. ${ }^{78}$ In particular, in the aftermath of the financial crises that erupted in 2008 the EU has been working towards the establishment of the Banking Union as an important step towards a genuine Economic and Monetary Union which could allow for the consistent application of EU banking rules in the participating Member States, and which could be equipped to tackle those problems caused in the aftermath of the crises by the close relationship between public sector finances and the banking sector. ${ }^{79}$

Against this background, since 2007 the ESCB has been exploring the potential statistical use for macroeconomic and financial stability purposes of the data contained in credit registries administered by Public Credit Bureaus, proving the analytical usefulness but outlining the differences of the data in terms of coverage, attributes, and content. This lack of standardisation and measurements, in turn, has pointed to the need for harmonisation in concepts and definitions, as well as for convergence in time, coverage and content of the data. ${ }^{80}$

Public credit bureaus in Europe have finalised a plan for a pan-European data exchange among the databases of Belgium, Germany, France, Italy, Austria, Portugal, and Spain, as well as representatives of the European Central Bank (later extended to Bulgaria, Czech Republic, Latvia, Lithuania, Romania, Slovenia, and Slovakia). The plan consisted in the creation of a reporting system allowing a data exchange on a regular basis on borrowers who also have debt in other European countries. The envisaged cross-border exchange was not intended for the consumer sector but to provide information to financial institutions across Europe about the indebtedness of their corporate customers. Also, the information exchange could provide useful additional information to supervisory authorities on credit concentration. For supervisory purposes, the growing internationalisation of lending to companies within the European Union, as well as the introduction of the single currency, required an exchange of information among national authorities in order to maintain the value of information contained in their databases. ${ }^{81}$

\footnotetext{
${ }^{75}$ See Articles 119 and 127 TFEU.

${ }^{76}$ Articles 127 and 282 TFEU.

${ }^{77}$ Council Regulation (EU) No 1024/2013 of 15 October 2013 conferring specific tasks on the European Central Bank concerning policies relating to the prudential supervision of credit institutions, OJ L287/63 29.10.2013, p. 63-89.

${ }^{78}$ See the official websites of the ECB at https://www.ecb.europa.eu/ecb/tasks/html/index.en.html and https://www.bankingsupervision.europa.eu/home/html/index.en.html.

${ }^{79}$ See the official website of the ECB at https://www.bankingsupervision.europa.eu/about/incontext/bankingunion/html/index.en.html.

${ }^{80}$ De Almeida and Damia (2014).

${ }^{81}$ As explicitly documented by the Deutsche Bundesbank (the Central Bank chairing the Working Group on Credit Registries), in fact, "data on the total amount of loans taken up will be available for each of the participating countries as well as on an aggregated basis. The data will also provide a breakdown into asset items and off balance-sheet transactions. There will be no cross-border exchange of information on loans to individuals" (emphasis added). See Deutsche Bundesbank, Press Release (7 June 2005), available at http://www.bundesbank.de/Redaktion /EN/Downloads/Press/Pressenotizen/2005/2005_06_07_credit_registers.pdf?_blob=publicationFile. See also European Central Bank, Memorandum of Understanding on the Exchange of Information Among National Central Credit Registers for the Purpose of Passing It on to Reporting Institutions (April 2010).
} 
However, the recent financial crisis and the impact of defaults of personal loans on the banking system have exacerbated the desirability for more credit-risk data to allow the ECB and ESCB to perform its responsibilities of monetary policy, price stability, the development and production of analyses and statistics, and - last but not least - for micro-prudential supervisory purposes.

Credit Bureaus, regardless of their legal form, are the major data channels for such a purpose.

Hence, the ECB and ESCB are exploring the potentials of household credit-risk data and they are working towards their standardisation in order to be able to have common ground to measure indebtedness and over-indebtedness.

The ECB and ESCB Task Force on Analytical Credit Datasets have launched the 'AnaCredit' project with the mandate of:

1. Identifying a core set of data to meet the main users' needs and elaborate on their scope;

2. Further analysing and considering harmonised concepts and definitions, and methodological enhancements of the data;

3. Estimating the costs to be incurred by the ESCB to set up a sharing system and that of the reporting agents; and

4. Considering the governance, as well as the legal and confidentiality issues for a centralised data sharing system, and preparing the appropriate legal instrument. ${ }^{82}$

The ultimate goal is to address micro- and macro-prudential issues in the supervision of the EU banking system alongside monetary policy.

The legal basis for the 'AnaCredit' project is the Decision of the ECB n. 6/2014 ${ }^{83}$ taken having regard of Article 5 of the Statute of the European System of Central Banks and the European Central Bank ${ }^{84}$ on the collection of statistical information.

The Statute of the ESCB and of the ECB is laid down in a Protocol annexed to the EU Treaties as provided for in the second paragraph of Article 129 of the Treaty on the Functioning of the European Union.

Article 5.1 of the Statute provides that in order to undertake the tasks of the ESCB, the ECB with the assistance of the national central banks has to collect the necessary statistical information either from the competent national authorities or directly from economic agents. To do so, it has to cooperate with the Union institutions and other agencies, as well as with the competent authorities of the Member States or third countries (in addition to the relevant international organisations). In turn, Article 5.2 states that the national central banks shall carry out, to the extent possible, the tasks of Article 5.1.

Of particular importance is Article 5.3 according to which "the ECB shall contribute to the harmonisation, where necessary, of the rules and practices governing the collection, compilation and distribution of statistics in the areas within its fields of competence".

The SSM Regulation ${ }^{85}$ conferring prudential supervisory powers to the ECB reinforces the legal basis of the activities undertaken under 'Anacredit'.

To carry out the supervisory activities required by Article 4 of the SSM Regulation, the ECB shall adopt guidelines and recommendations, and take decisions subject to and in compliance with the

\footnotetext{
${ }^{82}$ Damia and Israel (2014)

${ }^{83}$ Decision of the European Central Bank of 24 February 2014 on the organisation of preparatory measures for the collection of granular credit data by the European System of Central Banks (ECB/2014/6) (2014/192/EU), OJ L104/72 of 08.04.2014.

${ }^{84}$ OJ C $326 / 230$ of 26.10 .2012 .

${ }^{85}$ Supra note 77.
} 
relevant Union law. The ECB may also adopt regulations only to the extent necessary to organise or specify the arrangements for the carrying out of the tasks conferred on it by the SSM Regulation itself. ${ }^{86}$

The Decision of the ECB defines the preparatory measures which are deemed necessary to establish in the long term a framework for the collection of the data based on harmonised ECB statistical reporting requirements. ${ }^{87}$ It is addressed to the national Central Banks and the controllers of other credit registers or databases. ${ }^{88}$

According to hearsay evidence, the ECB plans to release a regulation regarding the issue of technical rules, procedures, and reporting thresholds, with an expectation of implementing a practical application of 'AnaCredit' by January 2017.

To do so, however, it should comply with the requirements set in the last limb of Article 4.3 of the SSM Regulation, according to which, where necessary, the ECB shall contribute in any participating role to the development of draft regulatory technical standards or implementing technical standards by the European Banking Authority or shall draw the attention of the European Banking Authority to a potential need to submit to the Commission draft standards amending existing regulatory or implementing technical standards. ${ }^{89}$

For the purpose of this study, 'AnaCredit' may have an important impact on the function and activities of Credit Bureaus, especially the private or commercial ones. On a purely speculative basis, it may be conceived that the standardisation of the measurement of over-indebtedness and the way to conduct creditworthiness assessment represent a back-door interference of the way Credit Bureaus conduct their business and the type of data they supply. Arguably, it will force them to adapt or rebuild their databases in order to remain up-to-date with regulatory requirements and/or competitive in the market. An extreme argument may consider them redundant to the extent that their role and functions may be substituted by the public authorities.

The bottom-line is that the ECB intervention, if and when implemented, has the potential to make a major impact on the way Credit Bureaus operate to the point of forcing them to evolve, or risk their own continued existence.

\section{Concluding Remarks}

This study explored the operations and the role of consumer Credit Bureaus in the Member States of the EU and it analysed their functions vis-à-vis the underlying economic theories and within the EU policy and legal framework.

Despite the attempts to harmonise the rules of credit to consumers for the creation of an EU internal market, the credit information infrastructure has been developed and it has remained jeopardised on a national basis. It appears that the current practice of credit data use in the Member States hardly contributes to achieve univocal, common, or defined policy objectives under the rule of law. Across the EU there is still a great variety in the type of data used for different purposes. The three main identified functions of Credit Bureaus that this work has identified are the supply of consumer information for the credit-risk management of financial institutions, the creditworthiness assessment of consumers, and the prudential supervision of banks. These different functions usually result in

\footnotetext{
${ }^{86}$ See Article 4.3 of the SSM Regulation.

${ }^{87}$ Article 1of ECB Decision, supra note 83.

${ }^{88}$ Articles 3 and 4 of ECB Decision, supra note 83.

${ }^{89}$ In accordance with Regulation (EU) No 1093/2010 of the European Parliament and of the Council of 24 November 2010 establishing a European Supervisory Authority (European Banking Authority), amending Decision No 716/2009/EC and repealing Commission Decision 2009/78/EC, OJ L 331/12.
} 
different legal forms of Credit Bureaus and their fragmentation into public and private or commercial Credit Bureaus.

Each function presents separate policy and legal issues which would need to be addressed separately.

Nevertheless, as far as consumer protection is concerned, key common features may be identified, especially if it is taken the angle of consumer over-indebtedness where, in a way or the other, all the explored functions converge. Consumer information is at the basis of each system and it needs to be balanced with the fundamental rights of privacy and data protection of individuals. Moreover, information may become the gateway of the economic and social life of people determining, inter alia, access conditions to services and consequently they may play a role in inclusion or exclusion in society in a broad sense. Therefore, the data need to be reliable and proportionate to achieve well identified policy objectives in the general interest. The fragmentation in the Member States question such reliability and proportionality as they all seem to have in place a diverse system but with no uniquely accepted criteria or standards.

In addition, to serve the interest of consumers, it is important that data are processed and used transparently to achieve these goals.

In the end, therefore, an analysis of the many functions and usages of credit data suggest that the policy goals to be achieved should inform the institutional or legal form of Credit Bureaus and/or the design and use of databases under the rule of law.

If information is not used within a proper framework, it can result in dysfunctional markets, market abuse, and major consumer detriment including social and financial exclusion, discrimination and, in some cases, abuse of fundamental rights.

Last but not least, it is difficult to conceive a single market in credit to consumers where the underlying information is not standardised. A jeopardised information infrastructure may serve as an obstacle to cross-border credit as well as the exercise of all other free movement rights which are at the basis of the EU. If a simple analogy is allowed in the interest of over-simplification, it is akin to building a common train for the EU which then needs to run on tracks built with different measures and designs.

Importantly, moreover, if the EU is to take seriously the side effect of consumer over-indebtedness which is typical of a liberalised credit market - it has to find reliable ways to measure it and to do so it needs a common basis of standardised data. In this context, this study has started to investigate new initiatives taken by the European Central Bank under its remit of collecting statistical data on the levels of indebtedness in the EU and the prudential supervision of the Euro area. The project of standardising data is still in its infancy but it stimulates speculations over a real need of having standardised data to achieve common policy objectives, which ultimately may have the potential of revolutionising the way in which Credit Bureaus operate in the EU. 


\section{Bibliography}

Admati AA and Pfleiderer PC, Forcing Firms to Talk: Financial Disclosure Regulation and Externalities, 13 Review of Financial Studies (2000), 479-519

Akelof G, The market for 'Lemons': Quality uncertainty and the market mechanism, 28(3) Quarterly Journal of Economics, (1970), 523-547

Alary D and Gollier C, Strategic Default and Penalties on the Credit Market with Potential Judgment Errors, EUI Working Paper, (European University Institute 2001)

Balmer NJ, Pleasence P, Buck A, and Walker H, Worried Sick: the Experience of Debt Problems and their Relationship with Health, Illness and Disability 5(1) Social Policy and Society (2006), $39-51$

Barron M and Staten S, The Value of Comprehensive Credit Reports: Lesson from the US Experience, Research Paper - Credit Research Centre, (Georgetown University 2000)

Barron M and Staten S, The Value of Comprehensive Credit Reports: Lesson from the US Experience, in Miller MJ (ed.), Reporting systems and the international economy (MIT Press 2003), 273-310

Berger AN and Udell GF, Relationship Lending and Lines of Credit in Small Firm Finance, 68 Journal of Business (1995), 351-381

Berthoud R and Kempson E, Credit and Debt: The PSI Report (PSI, 1992)

Bertola G, Disney R, and Grant C, The Economics of Consumer Credit Demand and Supply, in Bertola G, Disney R, and Grant C (eds.), The Economics of Consumer Credit (MIT Press 2006), $1-26$

Bigus JP, Data mining with neural networks: Solving business problems from application development to decision support (New York, McGraw Hill 1996)

Brealey RA, Clark A, Goodhart C, Healy J, Hoggarth G, Llewllyn DT, et al, Financial stability and central banks. (Routledge 2001)

Cartwright P, Banks, Consumers and Regulation (Hart Publishing 2004)

Caplovitz D, The Poor Pay More: Consumer Practices of Low Income Families (Free Press 1963)

Civic Consulting, The Over-Indebtedness of European Households: Updated Mapping of the Situation, Nature and Causes, Effects and Initiatives for Alleviating its Impact (Brussels, 2014)

Consumer Financial Protection Bureau, Analysis of Differences between Consumer- and CreditorPurchased Credit Scores (September 2012), at http://files.consumerfinance.gov/f/201209 _Analysis_Differences_Consumer_Credit.pdf

Damia V and Israel JM, Standardised granular credit and credit risk data, Seventh IFC Conference on Indicators to support Monetary and Financial Stability Analysis: Data Sources and Statistical Methodologies (Basel, 4 and 5 September 2014)

De Almeida AM and Damia V, Challenges and prospects for setting-up a European Union shared system on credit, IFC Bulletin No. 37 (January 2014)

Desai VS, Convay DG, Crook JN, and Overstree GA, Credit scoring models in the credit union improvement using_neural networks and genetic algorithms, 8 IMA J Mathematics Applied in Business and Industry (1997), 323-346

Diamond DW, Monitoring and Reputation: The Choice between Bank Loans and Directly Placed Debt, 99(4) Journal of Political Economy (1991), 689-721 
Dominy $\mathrm{N}$ and Kempson E, Can't Pay or won't Pay? A Review of Creditor and Debtor Approaches to the Non-Payment of Bills (DCA 2003)

Engel KC and McCoy PA, The Subprime Virus (Oxford University Press 2011)

European Commission, Report of the Expert Group on Credit Histories (Brussels, May 2009)

European Parliament, Responsible Lending - Barriers to Competition, DG For Internal Policies, Economic and Monetary Affairs, IP/A/ECON/ST/2011-05, Brussels: European Parliament (Brussels, June 2011)

Ferretti F, A European Perspective on Consumer Loans and the Role of Credit Registries: the Need to Reconcile Data Protection, Risk Management, Efficiency, Over-indebtedness, and a Better Prudential Supervision of the Financial System, 33(1) Journal of Consumer Policy (2010), 1-27

Ferretti F, The 'Credit Scoring Pandemic'and the European Vaccine: Making Sense of EU Data Protection Legislation, 1 Journal of Information Law and Technology (2009), 1-24, available at http://go.warwick.ac.uk/jilt/2009_1/ferretti

Ferretti F, The Law and Consumer Credit Reporting Systems in the EC (Routledge-Cavendish 2008)

Ferretti F, EU Competition Law, the Consumer Interest and Data Protection (Springer 2014)

Fractal Analytics, Comparative Analysis of Classification Techniques, A Fractal Whitepaper, (September 2003)

Giannetti C, Jentzsch N, Spagnolo G, Information-Sharing and Cross-Border Entry in European Banking, ECRI Research Report N. 11 (Brussels, February 2010)

Handzic M, Tjandrawibawa F, and Jeo J, How Neural Networks Can Help Loan Officers to Make Better Informed Application Decisions; Informing Science (2003), 97-109

Hendricks E, Credit Scores \& Credit Reports - How the System Really Works (Privacy Times 2004)

Hoermann G (ed.), Consumer Credit and Consumer Insolvency: Perspectives for Legal Policy from Europe and the USA (ZERP, 1986)

Jappelli $\mathrm{T}$ and Pagano M, The Role and Effects of Credit Information Sharing, in Bertola G, Disney R, and Grant C (eds.), The economics of consumer credit (MIT Press 2006), 347-371

Jappelli T and Pagano M, Information Sharing in Credit Markets: The European Experience, Working Paper No. 35, Centres for Studies in Economics and Finance, (University of Salerno 2000)

Jappelli T and Pagano M, Public Credit Information: A European Perspective, in Miller MJ (ed.), Reporting systems and the international economy. (MIT Press 2003), 81-114

Jappelli T and Pagano M, Information Sharing, Lending and Defaults: Cross-Country Evidence, 26(10) Journal of Banking and Finance (2002), 2017-2045

Jensen HL, Using Neural Networks for Credit Scoring, 18(6) Managerial Finance (1992), 15-26

Jentzsch N., The Regulation of Financial Privacy: The United States vs. Europe, ECRI Research Report No.5, European Credit Research Institute (Brussels, 2003)

Jentzsch N., The Economics and Regulation of Financial Privacy (Physica-Verlag 2006) 
Keys BJ, Mukherjee TK, Seru A, and Vig V, Did securitization lead to lax screening? Evidence from subprime loans, Working Paper prepared for the European Finance Association (Athens, 2008)

Klein DB, Promise Keeping in Great Society: a Model of Credit Information Sharing, 4(2) Economics and Politics (1992), 117-136,

Klein DB, Promise Keeping in the Great Society: a Model of Credit Information Sharing, in Klein DB (ed.), Reputation: Studies in the Voluntary Elicitation of Good Conduct, (University of Michigan Press 1997), 267-288

Lastra RM and Shams H, Public accountability in the financial sector, in Ferran E and Goodhart C (eds.), Regulating financial services and markets in the twenty first century (Hart Publishing 2001), 165-188

Lastra RM, Central banking and banking regulation (London, Financial Markets Group LSE 1996)

Metz R, Scoring: New Legislation in Germany, 35(3) Journal of Consumer Policy (2012), 297-305

Mierzwinski E and Chester J, Selling Consumers Not Lists: The New World of Digital DecisionMaking and the Role of the Fair Credit Reporting Act, 46(3) Suffolk University Law Review (2013), 845-880

Micklitz HW, The Regulation of Over-Indebtedness of Consumers in Europe, 35(4) Journal of Consumer Policy (2012), 417-419

Miller MJ, Introduction, in Miller MJ (ed.), Reporting Systems and the International Economy (MIT Press 2003 a), 1-23

Miller MJ, Credit Reporting Systems around the Globe: The State of the Art in Public Credit Registry and Private Credit Reporting Firms, in Miller MJ (ed.), Reporting Systems and the International Economy (MIT Press 2003 b), 25-79

Niemi J, Consumer Insolvency in the European Legal Context, 35(4) Journal of Consumer Policy (2012), 443-459

Niemi J, Consumer bankruptcy in comparison: do we cure a market failure or a social problem? 37 Osgoode Hall Law Journal (1999), 473-503

Odudu O, Indirect information exchange: the constituent elements of hub and spoke collusion, 7(2) European Competition Journal (2011), 205-242

Pagano M. and Jappelli T., Information Sharing in Credit Markets, 48(5) Journal of Finance (1993), 1693-1718

Poulton EC, Behavioural Decision Theory (Cambridge University Press 1994)

Ramsay I, Between Neo-Liberalism and the Social Market: Approaches to Debt Adjustment and Consumer Insolvency in the EU, 35(4) Journal of Consumer Policy (2012 a), 421-441

Ramsay I, A Tale of Two Debtors: Responding to the Shock of Over-Indebtedness in France and England - a Story from the Trente Piteuses, 75(2) Modern Law Review (2012 b), 212-248

Ramsay I, Consumer Law and Policy (Hart 2007)

Riestra ASJ, Credit bureaus in today's credit markets, ECRI Research Report No. 4 (European Credit Research Institute, Brussels, September 2002)

Stiglitz JE and Weiss A, Credit Rationing in Markets with Imperfect Information, 71(3) American Economic Review (1981), 393-410 
Thomas LC, A Survey of Credit and Behavioural Scoring: Forecasting Financial Risk of Lending to Consumers, 16(2) International Journal of Forecasting (2000), 149-172

Trumbull G, Consumer Lending in France and America (Cambridge University Press 2014)

Vandone D, Consumer credit in Europe (Physica-Verlag 2009)

Yobas M and Crook NJ, Credit Scoring Using Neural and Evolutionary Techniques 11 IMA Statistics in Financial Mathematics Applied in Business and Industry (2000), 111-125 

